\title{
Putting The Cart Before The Horse: Parent Involvement In The Improving America's Schools Act
}

\author{
Daniel Johnson $\dagger$
}

One of the most popular education reform measures is to increase parent involvement in schools. The federal government has played a leading role in promoting the concept. The largest federal education program, Title I of the Elementary and Secondary Education Act, has required schools to involve low-income parents in school programs for nearly 30 years. The Act's latest amendments, entitled the Improving America's Schools Act of 1994 (IASA), contain its most extensive parent involvement provisions to date. This Comment analyzes the IASA and draws upon the large body of research on parent involvement to argue that the law took a mistaken approach to getting low-income parents involved in schools. Instead of offering parents advisory roles in school policy-making, Title I should encourage schools to help low-income parents help their children learn. The author explains why, and proposes an alternative approach for the future.

\section{INTRODUCTION}

More than twenty years ago the nation focused its attention on a very poor inner-city elementary school in Chicago that substantially improved students' reading scores through parent involvement.' The school's program, dubbed "Operation Higher Achievement," was designed on the premise that "one reason middle-class children tend to do better in school than poor children is that they receive support and

Copyright 191997 California Law Review Inc.

$\dagger \quad$ Law clerk to the Honorable Carolyn R. Dimmick, United States District Court, Western Dist. Washington; B.A. 1990 The Evergreen State College; J.D. 1997, Boalt Hall School of Law, University of California at Berkeley. 1 am grateful to Professor Rachel Moran and editors Machaela Hoctor, Elise Crawford, Tom Ginsburg, and Tristin Green, and all their packeteers. For inspiration and insight I thank a great school teacher, Holly Swain.

1. See Merrill Sheils \& Sylvester Monroe, A New Kind of PTA, Newswekk, Nov. 15, 1976, at 105. 
encouragement from their parents at home."2 Albert Briggs, superintendent of the Chicago district, was convinced that low-income parents could do the same. He started the program at Ulysses S. Grant Elementary with a weekend parent-teacher conference. "We convinced [parents] that we wanted them-then showed them how to help."3

Teachers at the school began communicating with parents about helpful homework exercises. Parents began to visit classrooms to see what was happening and to help plan monthly book fairs and other educational events. The school began lending books and educational games to families for use at home. ${ }^{4}$ In the program's first year, the average reading level for the 400 participating children rose 1.1 years, nearly double the Chicago average. ${ }^{5}$

Since this story was first told, parent involvement has become one of the most common features of educational reform proposals. It is a regular topic of discussion in professional journals ${ }^{6}$ and the subject of scores of books for both professionals and parents. ${ }^{7}$ Federal, state, and school-district-level policymakers have placed parent involvement at the top of their agendas for school reform. ${ }^{8}$ President Clinton, in his 1997 State of the Union address, stressed the importance of parental involvement throughout a child's education.'

Federal appreciation of this strategy is not new. In fact, the federal government was a pioneer in making parent involvement a component of educational policy. Thirty-two years ago, Congress passed the

2. Id.

3. Id.

4. See id.

5. See id.

6. The following journal issues demonstrate the prevalence of parent involvenent as a topic of scholarship: 66 Educ. Horizons I (1988) and Educ. Leadership, Oct. 1989.

7. See a New Generation of Evidence: The family is Critical to Student AChievement ix (Anne T. Henderson \& Nancy Berla eds., 1994) [hereinafter New Gencration] (abstracting 66 studies, reviews, and books about parent involvement and describing the field as "a growth-industry"). See generally ANne T. Henderson, PARENTs Are Powerful (1996) (designed for parents as well as professionals); Carl L. Marburger, ONE School at a Time: ScIiool Based Management: A Process for Change (1985).

8. See, e.g., 105 Ill. Comp. Stat. ANn. 5/34-2.1(a) (West Supp. 1996) (creating local school councils in Chicago schools with majority parent membership); U.S. DEr'T of Educ., Strong Families, Strong Schools: Building Community Partnerships for Learning 4 (1994) ("U.S. Secretary of Education Richard Riley has proposed ... an initiative that brings together an informal coalition of groups and individuals dedicated to increasing family involvement in lcarning and placing it high on the American agenda."). See generally Janet $\mathrm{H}$. Chrispeels, District Leadership in Parent Involvement: Policies and Actions in San Diego, 72 PHI DelTA Kappan 367 (1991) (detailing parent involvement initiatives in San Diego); Zelma P. Solomon, California's Policy on Parent Involvement: State Leadership for Local Initiatives, 72 PHI DeLTA KAPPAN 359 (1991) (discussing California's policy on parent involvement).

9. See Text of President Clinton's State of the Union Message, N.Y. TimEs, Feb. 5, 1997, at Al4. 
Elementary and Secondary Education Act of 1965 (ESEA), ${ }^{10}$ and, shortly thereafter, regulations pursuant to Title I of the Act required parent involvement in recipient school systems. ${ }^{11}$ Parent involvement has appeared in the statute itself since 1970. ${ }^{12}$ Title I was and is a massive compensatory aid program, aimed at raising student achievement among economically and educationally disadvantaged students. ${ }^{13}$ By making parent involvement a component of this effort, the federal government indicated that involving parents, particularly low-income parents, in their children's schools was a viable solution to educational inequities.

In 1994, Congress passed the Improving America's Schools Act of 1994 (IASA), ${ }^{14}$ which reauthorized Title I and made significant changes to its parent involvement section. ${ }^{15}$ Title $I$ is the mainstay of federal education policy, and its influence is broad-sweeping. ${ }^{16}$ The law's prominence suggests that its provisions should reflect careful policy choices. This Comment examines the IASA's provisions on parent involvement. It argues that, in light of educational research and practice, the Act mistakenly emphasizes giving parents advisory roles at the expense of helping schools involve parents directly in their children's learning. As a result, the law is unlikely to encourage increased parent involvement or raise academic achievement. Assuming the federal government can play some role in effecting improved parent participation in schools, this Comment demonstrates that this role must be modest and simple. Title I should focus schools on involving parents in their own children's learning through increased contact with and support of parents.

10. Elementary and Secondary Education Act of 1965, Pub. L. No. 89-10, 79 Stat. 27 (codified as amended in scattered sections of 20 U.S.C.). See generally Joan L. Herman \& Jennie P. Yeh, Some Effects of Parent Involvement in Schools, 15 URB. REv. 11 (1983) (discussing impact of ESEA).

11. See 45 C.F.R. \$ 116.18(f) (1968) (repealed 1971).

12. See infra note 78 and accompanying text.

13. See Elementary and Secondary Educ. Div., U.S. Dep't of Educ, Mapping Out the National Assessment of Title 1: The Interim Report, Executive Summary 1-3 (1996).

14. Improving America's Schools Act of 1994, 20 U.S.C. $\$ 6301$ et seq. (1994). A word on nomenclature: The IASA is the Iatest of many reauthorization and amendments to the ESEA, but the latter term is still used to refer generally to the education act, regardless of the specific version referenced. The term "1ASA" will refer to the specific provisions in the 1994 amendments; and "ESEA" to the historical life of the statute. Title I, which has always made up the bulk of the ESEA, may be used in either the historical or contemporary sense.

15. Compare 20 U.S.C. $\S 6319$ (1994) with Augustus F. Hawkins-Robert T. Stafford Elementary and Secondary School Improvement Amendments of 1988, Pub L. No. 100-297, § 1016, 102 Stat. 140, 157.

16. See Oliver C. Moles, Synthesis of Recent Research on Parent Participation in Children's Education, EDuc. LEADERShip, Nov. 1982, at 44 (gauging the efficacy of parent involvement activities under Title I and other programs); Robert Marshall Wells, Move to Revise School Aid Heads for Troubled Times, 52 CoNG. Q. 1308, 1309 (1994) (indicating that millions of dollars in aid is distributed to every state in the nation pursuant to Chapter 1 ). 
Part I of this Comment presents the findings of current research on parent involvement in schools serving low-income children. It describes the theoretical justification for schools to involve parents and the different approaches that have been used in developing parent-involvement programs. Part II traces the parent-involvement provisions of Title I, from their origins in 1968 to the new provisions in the 1994 reauthorization. Part III uses educational literature and findings of federal policymakers to argue that, especially for the federal government, an approach that focuses on parent-child learning activities is superior to one focusing on parent involvement in school decision-making. Part IV presents proposals for Title I parent involvement and addresses some problems left unresolved by those proposals.

I

\section{What is Parent Involvement?: Educational LITERATURE AND EXPERIENCE}

\section{A. Why Parent Involvement?}

The virtually unified main goal of parent involvement initiatives is to raise students' academic achievement. ${ }^{17}$ Both Congress and the Administration identified improved academic performance as the chief objective for promoting parent involvement in Title $I .{ }^{18}$ Research on the connection between parent involvement and higher student achievement has proliferated in the years since $1968 .{ }^{19}$ Scholars and practitioners have suggested that involving parents in the schools provides several benefits to students, including improvements in behavior, attendance, attitudes toward school, and homework habits, all of which contribute to higher achievement. ${ }^{20}$

Moreover, evidence amply demonstrates that parent involvement in Title I programs is a sound policy objective. Most of the existing literature focuses either explicitly or implicitly on the low-income and marginalized parents and children who make up the Title I population.

17. See, e.g., New Generation, supra note 7, at 1; Milbrey Wallin McLaughlin \& Patrick M. Shields, Involving Low-Income Parents in the Schools: A Role for Policy?, 69 P11I DeLTA KarpaN 156, 157 (1987).

18. The House Committee on Education and Labor stressed the children's "high performance" and "achievement" as goals of the parent involvement provisions of the IASA. See H.R. REP. No. 103-425, at 9 (1994). In responding to public comment on parent involvement in the $1 \mathrm{ASA}$, the Secretary of Education wrote that "the progress of a school is measured on the basis of student achievement, not the process to elicit that achievement." 60 Fed. Reg. 34,819 (1995).

19. For a review of the research on parent involvement in schools, see NORM FruCHTER ET al., New Directions in Parent Involvement (1992); Joyce L. Epstein, School and Family Partnerships, in 4 ENCYCLOPEdia of EduC. ResearCh 1139 (Marvin C. Alkin ed., 6th ed. 1992).

20. See Kathleen V. Hoover-Dempsey et al., Parent Involvement: Contributions of Teacher Efficacy, School Socioeconomic Status, and Other School Characteristics, 24 AMER. EdUC. RESEARCH J. 417,418 (1987). 
Further, most programmatic experiments in this field target low-income, low-achieving schools - often those with large minority populations. ${ }^{21}$ This research suggests several reasons for applying parent involvement solutions to low-income schools.

First, low-income parents, like most parents, want to help their children succeed, but they need support to do this. Studies show that parents' education level and availability are unrelated to their interest in participating in their children's education. ${ }^{22}$ Nevertheless, many lowincome parents feel they need more information about school programs before they can help than do their higher-income counterparts. ${ }^{23}$

Second, low-income children especially need strong school-family cooperation. Evidence clearly establishes that children whose parents are involved in their education do better in school. ${ }^{24}$ Studies of low-income families and their children's school performance suggest that this relationship is a function of the degree of continuity between school and home environments. ${ }^{25}$ Schools, as institutions administered within a "traditional middle-class framework," may be less hospitable and accessible to low-income and minority parents, whose children "have the best chance at a smooth transition from home to school when there are strong home-school connections."26

James P. Comer, a child psychiatrist and director of a long-running and successful parent involvement program in New Haven, Connecticut, ${ }^{27}$ emphasizes disadvantaged children's needs for homeschool cooperation. "The seemingly intractable problems of urban education are due in large measure to the failure of urban schools to incorporate elements of urban students' primary social networks into the teaching and learning process. ${ }^{228}$ Comer notes that when discontinuities between school and home are extreme, as is often the case in inner cities, a child may receive mixed messages from home, identifying the school or teacher as both a friend and an enemy. ${ }^{29} \mathrm{He}$ also describes how, particularly in poor urban schools, many children arrive having had disrupted or ineffective developmental relationships with their

21. See Fruchter ET Al., supra note 19, at 92-93; NEW Generation, supra note 7, at 1 .

22. See Moles, supra note 16 , at 45.

23. See Epstein, supra note 19, at 1142.

24. See NEw GENERATION, supra note 7, at 1.

25. See Luis M. Laosa, School, Occupation, Culture, and Family: The Impact of Parental Schooling on the Parent-Child Relationship, in ChangIng Familes 79, $92-93$ (Irving E. Sigel \& Luis M. Laosa, eds., 1983).

26. Patricia P. Olmstead, Parent Involvement in Elementary Education: Findings and Suggestions from the Follow Through Program, 91 Elementary SchOoL J. 220, 220 (1991).

27. See generally JAMEs P. COMER, SCHOOL POWER (1980) (describing the program).

28. James P. Comer, M.C., Educational Accountability: A Shared Responsibility Between Parents and Schools, 4 STAN. L. \& Pol'Y REv. 113, 116 (1992/93).

29. See James P. Comer, M.D., Improving the Quality and Continuity of Relationslips in Two Inner-City Schools, 15 J. Amer. ACAD. Child Psychiatry 535, 537 (1976). 
primary caretakers. ${ }^{30}$ Because school curriculum and classroom structure are usually geared toward the developmental level of children without these problems, what begins as a developmental lag may soon be treated as academic failure. ${ }^{31}$ This makes home-school collaboration especially important for disadvantaged children.

Third, parent involvement can succeed in raising the academic achievement of low-income children. The research indicates that while less-educated or poor parents are generally less likely to be involved than their middle-class counterparts, they do become involved under certain conditions, and this involvement is accompanied by a rise in their children's school success. ${ }^{32}$

Comer found that when parents participate in activities during the school day, "children identify with the enthusiasm and dedication of these parents, and seek to imitate their involvement ...."33 Others have found that home visits by school staff can be effective in inspiring parents to use creative learning activities at home, thus increasing the "linkage" between homework and school. ${ }^{34}$ In addition, parents' familiarity with the school program can improve their children's success by reinforcing the principles and concepts that they are learning at school, ${ }^{35}$ and by simply enabling parents to talk with their children about school. ${ }^{36}$

The work of Comer and others suggests that discontinuity between home and school is not caused by economic and cultural differences between parents and teachers. ${ }^{37}$ Rather, it is caused by organizational arrangements that impede cooperation and perpetuate 'teachers' and parents' stereotypes, misperceptions, and lack of understanding of mutual needs." ${ }^{38}$ If this is the case, organizational rearrangements and proper training for parents, teachers, and administrators should be able to achieve a more harmonious school experience for disadvantaged children.

30. See id. at 535 .

31. See id. at 536 .

32. See Phyllis J. Hobson, The Partnership With Title I Parents, in PARTNERs: Parents AND Schools 41, 41 (Ronald S. Brandt ed., 1979).

33. Comer, supra note 28 , at 119.

34. See Olmstead, supra note 26 , at 227.

35. See Herman \& Yeh, supra note 10 , at 11 .

36. See Sanford M. Dombusch \& Philip L. Ritter, Parents of High School Students: A Neglected Resource, 66 Educ. HoRizons 75, 76 (1988).

37. See Comer, supra note 29, at 538; see also Moles, supra note 16, at 46.

38. M. Laurie Leitch \& Sandra S. Tangri, Barriers to Home-School Collaburation, 66 Educ. HORIzONS 70, 70 (1988). 


\section{B. Techniques for Involving Parents in Schools}

In the last thirty years, U.S. schools have developed a variety of methods to realize the advantages of parent involvement. Parents are involved in schools in many ways, ranging from attending open houses and parent-teacher conferences to collaborating with school staff on budget and curriculum planning. Two broad types of parent involvement emerge from a review of the literature on the subject: parent participation in educational activities with their own children and parent involvement in school operations, primarily through decision-making or advisory groups. ${ }^{39}$ These two types of parent involvement programs have been called "parent impact" and "school impact" models. ${ }^{40}$ The two models have fundamentally different goals: "In the Parent Impact Model, the family learns to deal with agencies and schools as they are; in the School or Agency Impact Model, the goal of parent involvement is to change the school or agency and make it more responsive to the family as it is." ${ }^{.41}$

\section{The Parent Impact Model}

The first type of parent involvement derives from the "traditional" model of parent-school relations. ${ }^{42}$ Schools are responsible for communicating with parents about their children's activities and progress and about events the school plans for parents, such as open houses or holiday presentations. Parents are responsible for responding to such communications, attending annual parent-teacher conferences, and providing home conditions that encourage their children to behave properly and complete their schoolwork.

Beyond simply increasing the volume of contact, such as having more conferences and special events for parents, the parent impact model seeks to influence the nature of those contacts by providing parents with resources and training to improve the support they can provide

39. See, e.g., Fruchter ET AL., supra note 19, at i-ii (dividing its review of model programs according to whether the focus is the parents or the school).

40. See Ira Gordon, The Effects of Parent Involvement on Schooling, in PARTNERs: PARENTS AND Schools, supra note 32, at 4,6-8; see also Hazel Leler, Parent Education and Involvement in Relation to the Schools and to Parents of School-Aged Children, in PARENT EDucation AND PUBLIC Policy 141, 141-44 (Ron Haskins \& Diane Adams eds., 1983). A third type of parent involvement program is discussed by these writers, which they call the "community impact model." This strategy is the most comprehensive and least common, and I exclude it from this discussion on the premise that Title I is far too large and broadly applied to induce successfully the community-based reformation this model contemplates.

41. Leler, supra note 40 , at 143 .

42. The following discussion borrows chiefly from Epstein, supra note 19, at 1145-46. For other discussions of the various types of parent involvement in schools, see Comer, supra note 28, at 11621; Carl L. Marburger, Education Reform: The Neglected Dimension, Parent Involvement, in Education Reform 82, 84-87 (Samuel B. Bacharach ed., 1990). 
to their children's learning. This model emphasizes improved schoolparent communication combined with innovative outreach and training for parents to work with their children in learning activities at home. ${ }^{43}$ It also may include recruiting parents to work as assistants in classrooms or other school settings, usually as volunteers but sometimes as paid aides. $^{44}$

\section{The School Impact Model}

The school impact model of parent involvement explicitly seeks to alter the structure of power in schools and districts through decentralization. This stems from the belief that such reorganization can make the schools more effective in educating students and more responsive to family needs. ${ }^{45}$ Viewing school failure as a part of the overall marginalization of poor communities, community-empowerment programs have utilized parent involvement in schools as a means of inspiring and enabling people to improve the schools as community institutions. One commentator writes, "Schools are key institutions in local communities and thus are in a special position to enhance or retard the empowerment process." 46 Another declares:

For a long time, we have understood that the magic of suburban schools is not merely the relative affluence and abundant resources of the citizens (nor their whiteness), but also the balance of power between families and schools, the sense of responsibility and accountability teachers feel for the educational success of children, and the parent's sense of entitlement in demanding results from schools. ${ }^{47}$

43. See. e.g., FruCHTER ET AL., supra note 19, at 40-43 (describing five programs that emphasize home learning activities).

44. See, e.g., James P. Comer, M.D., Parent Participation in Schools: The School Development Program as a Model, Family Resource Coalition RPT., 1989 No. 2, at 4.

45. See Leler, supra note 40 , at 143 . The concept of decentralizing decision-making in schools has its roots in the community empowerment struggles of the 1960 s and ' 70 s, which produced lawsuits in some cities. See FRUCHTER ET AL., supra note 19, at 69-70; Charles J. Russo, School-Based Decision Making in Kentucky: Dawn of a New Era or Nothing New Under the Sun?, 83 KY. L.J. 123, 130-34 (1994-95). The concept also helped fuel the Johnson Administration's War on Poverty, primarily its Community Action Programs, which mandated "maximum feasible participation" of the poor clients served by such programs. See Economic Opportunity Act of 1964, Pub. L. No. 88-452, \$ 202(a)(3), 78 Stat. 508, 516 (1964); see also Lois S. Steinberg, The Changing Role of Parent Groups in Educational Decision Making, in PARTNERs: PARENTS AND Schools, supra note 32, at 46,48 (discussing implementation of the Economic Opportunity Act). For a discussion of the Community Action Programs and their participation mandate, see generally ANNE AUSTIN MURPHY, INVOLving The POOR IN THE WAR Against Poverty (1970).

46. Moncrieff Cochran \& Christiann Dean, Home-School Relations and the Empowerment Process, 91 ElEm. ScH. J. 261, 261 (1991).

47. Sara Lawrence Lightfoot, Toward Conflict and Resolution: Relationships Between Families and Schools, 20 THEORY INTO PRACTICE 97, 101 (1981). 
A central feature of the school impact model is involvement of parents in decision-making roles, often through advisory committees or governance teams. ${ }^{48}$ Areas of influence can range from staffing the school, selecting curricula, and allocating resources, to designing programs for other parents to participate in school and home activities. ${ }^{49}$

The school impact model has also appeared in "school improvement" programs, a term used to describe a variety of school reform initiatives that aim to revitalize school operations, often with parents as critical participants. ${ }^{50}$ These programs are usually initiated locally, sometimes using strategies designed by private or university-based groups. ${ }^{51}$

\section{Parent Impact v. School Impact}

In practice, the parent impact and school impact models often overlap. Several prominent researchers in the field of parent involvement have concluded that schools must give parents a variety of roles to choose from in order to achieve effective parent involvement. ${ }^{52}$ Moreover, parent impact programs, however constituted, might work changes on the schools as a result of increased and more intense contacts with parents. ${ }^{53}$ Similarly, one might expect common parental roles to appear regardless of the model chosen. For example, the technique of having parents volunteer in their children's classrooms would be likely to impact the parents' ability to teach their children, while also leading those same parents to advocate for changes in the school's policies or budget allocations.

48. See Fruchter ET AL., supra note 19, at 50-51 (describing four school improvement plans that emphasize parent participation in decision making); Leler, supra note 40, at 163.

49. See Allen Fisher, Advisory Committees-Does Anybody Want Their Advice?, 37 Educ. Leadership 254, 255 (1979); Donald R. Moore, The Case for Parent and Community Involvement, in Empowering Teachers and Parents 131, 150-51 (G. Alfred Hess Jr. ed., 1992).

50. See FrUChTER ET AL., supra note 19, at 49-51. There is also a vast body of literature and experimentation on what is known as "School-Based Management" (SBM) and "Shared Decision Making," which denote a systemie decentralization of authority and a technique for exercising that authority, respectively. See id. at 70. See generally Betty Malen et al., What Do We Know About School-Based Management?: A Case Study of the Literature-A Call for Research, in 2 CHOICE AND Control in American Education 289 (William H. Clune \& John F. Witte eds., 1990). SBM has been taken up by legislatures in several states, often with teachers and other school staff as the primary players. Parents are often marginal players. See HARRY P. HATRY ET AL., IMPLEMENTING SChOOL-BASEd MANAGEMENT 57-59 (1993).

51 See FrUChTER ET AL., supra note 19, at 50-54. James Comer's School Development Program, initiated in New Haven, Conn., is one such program. See supra note 27 and accompanying text.

52. See Epstein, supra note 19, at 1146; Dorothy Rich et al., Families as Educators of Their Own Children, in PARTNERS: PARENTS AND Schools, supra note 32, at 26, 36.

53. See FRUCHTER ET Al., supra note 19, at 46 (noting that all of the home-oriented programs reviewed "seek to change traditional school practices to confront and reduce barriers to involvement"). 
Nonetheless, the two models represent different approaches to remedying low achievement in schools, and distinguishing them proves useful in the analysis below. Dan Lewis and Kathryn Nakagawa offer a valuable distinction between parent empowerment and parent enablement, which roughly corresponds to the school-and parent impact models described above. ${ }^{54}$ They write that empowerment models of parent involvement treat parents as agents of change whose participation in governance would make school bureaucracies more responsive to their children's needs. ${ }^{55}$ In contrast, parent enablement models assume that the initiative for meaningful change comes from school professionals themselves, whose "enlightened programming and innovative leadership" are harnessed to help parents help their children. "Whereas the empowerment camp emphasizes power over the educational enterprise, the enablement approach pushes for more parental commitment to the educational enterprise." 57

This philosophical difference is extremely important in analyzing the efficacy of parent involvement in Title I. Recall that one of the theoretical reasons for targeting low-income schools for parent involvement is the need for increased continuity between the home and school environments. The school impact, or empowerment, approach requires school officials to accommodate the perspectives of parents, whereas the parent impact or enablement approach suggests that school officials assist parents in furthering the schools' goals. While locally designed parent involvement programs may be able to strike a balance between these approaches, a federal mandate like that in Title I should be especially clear about how much structural change the schools are required to make, because federal policymakers are not present in the implementation process. Following a description of the parent involvement provisions of the IASA in Section II below, Section III demonstrates that those provisions emphasized school impact approaches without committing schools to structural change. Such change cannot occur without significant local initiative, a force that cannot be provided by federal statute. Instead, Title I would be served best by the parent impact model, a more modest but likely more effective approach to parent involvement in schools.

54. See Dan A. Lewis \& Kathryn Nakagawa, Race and Educational Reform in the American Metropolis 13-14 (1995).

55. See id. at 12.

56. Id. at 14.

57. Id. 
II

\section{The Improving AmericA's Schools ACT of 1994}

\section{A. Background and General Changes}

The Elementary and Secondary Education Act of 1965 (ESEA) $^{58}$ is the mainstay of federal aid to public elementary and secondary schools. Enacted as part of the Johnson Administration's War on Poverty, the ESEA is now a seven billion dollar program of compensatory aid for low-income students. ${ }^{59}$ Title I dominates the Act, allocating direct aid to about 90 percent of the nation's school districts, based on the income levels of the children in their regions and average state spending per pupil. ${ }^{60}$

The ESEA has been subject to several comprehensive amendments, of which the Improving America's Schools Act of 1994 (IASA) $^{61}$ is the most recent and one of the most dramatic. When the ESEA's budget allocation was due to expire in 1993, the Clinton Administration proposed significant new directions for the program, the bulk of which were included in the final version of the IASA bill, which was signed on October 20, $1994 .^{62}$

One of the aims of the new law was to increase the flexibility of schools and districts in their use of federal funds. ${ }^{63}$ Under the law, districts can allocate Title I funds to schools in one of two ways: as "targeted assistance" grants, which fund special remedial services for qualifying children, or as "school-wide program" grants, which can be used to upgrade the entire educational program. ${ }^{64}$ Prior to the 1994 amendments, schools could qualify for school-wide grants only if seventy-five percent of their children were from low-income families. ${ }^{65}$ The new law retains the distinction, but the threshold number of low-income students was reduced to sixty percent in the 1995-96 school year, and fifty percent in the years following. ${ }^{66}$ In addition, schools with qualifying school-wide programs may now combine Title I grants with funds

58. Elementary and Secondary Education Act of 1965, Pub. L. No. 89-10, 79 Stat. 27 (codified as amended in scattered sections of 20 U.S.C.)

59. See 20 U.S.C. $\$ 6302$ (a) (1994) (allocating $\$ 7.4$ billion for fiscal year 1995).

60. See Robert Marshall Wells, Education Bills Compared, 52 Cong. Q. 2619, 2619 (1994).

61. Improving America's Schools Act of 1994, 20 U.S.C. $\$ 6301$ et seq. (1994).

62. See id. $\$ 630 I$ (effective dates).

63. See H.R. REP. No. 103-425, at 4 (I994).

64. See Augustus F. Hawkins-Robert T. Stafford Elementary and Secondary School Improvement Amendments of 1988, Pub. L. No. I00-297, \$\$ I014-I015, 102 Stat. 140, 153-54. The law did not use the term "targeted assistance," but this is the common term applied to the requirement that, in the absence of a school-wide program, only qualifying children receive Title I services. See, e.g., Margot Rogers, Planning for Title I Programs: Guidelines for Parents, Advocates AND EdUCATORS 3 (1995).

65. See § 1015,102 Stat. at 154.

66. See 20 U.S.C. $\$$ 63I4(a)(1). 
from most other federal programs, as long as these schools meet "the intents and purposes" of those other programs. ${ }^{67}$ This change was aimed at allowing more schools and districts to develop continuity between federally-assisted programs rather than having to provide separate services to specific target populations. ${ }^{68}$

Another major aim of the new law was to apply the same standards to Title I children as all other children within a state. ${ }^{69}$ "Challenging standards"70 and "high quality, yearly assessments" oped by the states, and the success of Title I programs shall be measured by those standards. ${ }^{72}$ This change addresses the widespread protest that Title I programs gave a second-class education to low-income students by imposing low expectations. ${ }^{73}$

\section{B. Parent Involvement Provisions}

\section{The Prior Law on Parent Involvement}

Parent involvement first appeared in Title I through regulations promulgated in $1968 .^{74}$ Since then it has appeared in ever larger subsections of the statute itself, standing as national testimony of the concept's place in education reform. ${ }^{75}$ The 1994 amendments, officials and commentators say, expand parents' opportunities for involvement even further. ${ }^{76}$ However, while the IASA adds some substantive provisions to the ESEA, the IASA's approach to parent involvement is not new.

67. See Exemption Notice, 60 Fed. Reg. 49,174 (1995).

68. See id.

69. See H.R. Rep. No. 103-425, at 3-4 (1994).

70. 20 U.S.C. $\S 6311(b)(1)$.

71. See id. $\S 6311(b)(3)$.

72. See id. \$6311(b)(3)(A). The Secretary of Education may withhold "administrative funds" from states that do not create adequate standards and assessments. See id. $\$ 6311(d)(2)$. Whether the Secretary may withhold such funds from states where schools fail to produce positive results under the standards and assessments is unclear. The statute allows states to define the "adequate yearly progress" of Title ! recipient schools, but also requires such definition to conform to the Secretary's guidelines. Id. $\$ 6311(\mathrm{~b})(2)$.

73. See Hearing on H.R. 3130: Improving America's School Act of 1993: Hearing Before the Subcomm. on Elementary, Secondary, and Vocational Education of the House Conm. on Education and Labor, 103d Cong. 12 (1994) [hereinafter Hearing on H.R. 3130] (statement of Richard Rilcy, Secretary, Dep't. of Educ.); Jill Zuckman, Funding Fights to Doninate it Chapter I Rewrite, 51 CoNG. Q. 1146. 1151 (1993).

74. See 45 C.F.R. \& 116.18(f) (1969) (repealed 1971) (requiring "maximum practical involvement of parents ... in planning, development, operation, and appraisal of [the district's] projects, including their representation on advisory committees which may be established for the local Title I program").

75. See, e.g., FRUCHTER ET AL., supra note 19, at 1-2.

76. See Promising Practices: Parental Involvement in School: Hearing Before the Subcomm. on Education, Arts and the Humanities of the Senate Comm. on Labor and Human Resources, 103d Cong. 10 (1994) [hereinafter Promising Practices] (statement of Richard Riley, Secretary, Dep't. of Educ.); H.R. ReP. No. 103-425, at 725-26 (1994); RoGERS, supra note 64, at 3-4, 6. 
From 1968 to 1981, the ESEA used parent-advisory councils ("PACs") as the primary mechanism to encourage parent involvement. ${ }^{77}$ Generally, federal law required school district authorities to form and utilize PACs in designing the educational programs funded by Title I. ${ }^{78}$ However, in 1981 the Reagan Administration reduced the ESEA to a block grant with very few strings attached. ${ }^{79}$ School districts were only required to assure state authorities that parents were "consulted," along with teachers, in designing the programs to be funded. ${ }^{80}$ Technical amendments added in 1983 required each district to convene an annual meeting of parents to inform them of the programs and activities being funded under Title I and allowed the districts to "provide reasonable support" when "parents desire further activities." 81

In 1988, the ESEA was amended significantly, expanding the parent involvement provisions. However, the PACs returned only as optional mechanisms for involving parents. ${ }^{82}$ Instead, the law described goals that the school districts were to pursue, including informing parents about Title I and their children's participation; supporting and training parents to do homework with their children and helping them to understand Title I's requirements; training teachers and staff to work effectively with Title I parents; consulting with parents about building better home-school partnerships; and involving parents who lack literacy skills. ${ }^{83}$ The law mandated four mechanisms for pursuing these goals: Districts were to (1) develop written parent involvement policies "after consultation with and review by parents;"84 (2) "convene an annual meeting" to explain Title I programs to parents; ${ }^{85}$ (3) provide parents with reports on their children's progress;" and (4) "provide opportunities for regular meetings of parents" if they "so desire."

77. See Education Amendments of 1978, Pub. L. No. 95-561, § 125, 92 Stat. 2143, 2167 (requiring PACs at the school and district levels); Education Amendments of 1974, Pub. L. No. 93$380, \S 101,88$ Stat. 484, 497 (requiring PACs at the school and district levels); Elementary and Secondary Education Amendments of 1970, Pub. L. No. 91-230, § 415, 84 Stat. 121, 168 (allowing PACs at the state and district levels); 45 C.F.R. $\S 116.18$ (f) (1968) (repealed 1971) (urging PACs at the district level).

78. See, e.g., Education Amendments of $1974 \$ 101$ (requiring districts and schools to establish councils that have a majority parent membership and that advise "in the planning for, and the implementation and evaluation of," Title 1 projects).

79. See Education Consolidation and lmprovement Act of 198I, Pub. L. No. 97-35, § 561, 95 Stat. $463,469$.

80. See id. \$ 556(b)(3), 95 Stat. at 466.

81. Act of Dec. 8, 1983, Pub. L. No. 98-211, § 4, 97 Stat. 1412, 1414.

82. See Augustus F. Hawkins-Robert T. Stafford Elementary and Secondary School Improvement Amendments of 1988, Pub. L. No. 100-297, § 1016(c)(5), 102 Stat. 140, 157.

83. See id. $\$ 1016(\mathrm{~b})$.

84. Id. \$ 1016(c)(1).

85. Id. $\S 1016(\mathrm{c})(2)$.

86. See id. § 1016(c)(3).

87. Id. $\S 1016(\mathrm{c})(4)(\mathrm{A})$. 
The law then provided a long list of optional mechanisms that districts could use to enhance parent participation. ${ }^{88}$

Thus, portions of the 1988 law, particularly its reference to schools helping parents do homework projects with their children, reflect a shift from parent advisory roles-school impact techniques-to parent impact techniques. However, this reference appeared only as a goal ${ }^{89}$ and was not supported by the specific mechanisms required under the law. ${ }^{90}$ Also, the 1988 law was directed at districts, not schools, which further reduced the law's capacity to inspire school-site staff to help parents work with their children. In any case, the Department of Education found the structure of the 1988 law "confusing," and in its effort to clarify the structure in the 1994 law, further diminished its concern with parent impact techniques.

\section{The Current Law on Parent Involvement}

The 1994 amendments to the ESEA substantially reorganized the section on parent involvement and made its provisions applicable to schools as well as districts. Parent advisory roles are now back at the center of the Act's prescriptions as a primary vehicle to spur parent involvement and participation..$^{92}$ The IASA also contains a new requirement that schools establish a compact of shared responsibility between the school and each Title I parent. ${ }^{93}$ In addition, the Act reorganized and strengthened many of the other provisions on parent involvement, requiring districts and schools to take a number of steps to "build capacity" for parent involvement. ${ }^{94}$

To better illustrate the meaning of IASA's statutory language and how schools might interpret and implement it, I refer throughout this section to a particular elementary school's progress with Title I parent involvement. Hesperian School is a public elementary school in San Lorenzo, California, whose students come from very diverse ethnic backgrounds, but from predominantly low-income families. The IASA enabled Hesperian to switch from a targeted assistance program, in which funds can be used only to help qualifying children, to a schoolwide program, which allows the funds to be broadly applied. ${ }^{95}$ Hesperian recently had a "compliance review," an audit of its Title I expenditures

88. See id. \$ 1016(c)(5).

89. See id. \& 1016(b)(2).

90. See id. § $1016(\mathrm{c})$.

91. Telephone Interview with Jessica Levin, General Counsel's Office, U.S. Dep't. of Educ. (March 28, 1996).

92. See 20 U.S.C. § 6319(a)-(c) (1994).

93. See id. \$ 6319(d).

94. See id. \$ 6319(e).

95. See supra note 64 and accompanying text. 
by California Department of Education officials. ${ }^{96}$ Thus, at this writing, Hesperian is very busy reviewing and reforming its Title I programs, including its parent involvement program.

\section{a. Parent advisory roles}

As under the former provisions, the current law does not specifically mandate parent advisory councils at any level of a public school system. The IASA does impose, however, considerably more detailed "consultation" requirements on schools and districts. ${ }^{97}$ These consultation requirements are complex, multi-layered creatures that envision parent involvement in a variety of capacities.

\section{i. District-level advisory roles}

At the district level, parents must be involved in developing the mandated district-wide parent involvement policy. ${ }^{98}$ The policy must describe how parents will be involved in the substantive work of developing the district's overall Title I plan for standard setting, school selection and funds distribution, instructional guidance, student assessments, and program evaluation. ${ }^{99}$ Thus, the district should include parents in the planning of parent involvement, focusing on the role of parents in planning substantive educational programs.

Arguably, the statute contemplates a representative body of parents, such as a parent advisory council. However, a district that consulted informally with only one or two parents in the plan-development phases may meet the law's requirements. ${ }^{100}$ The decision not to prescribe the exact form that parent advice should take reflects the Administration's

96. See Interview with Barbara DeBarger, Principal, Hesperian School, San Lorenzo, Cal. (Mar. 27, 1996).

97. The Act also requires State Education Agencies ("SEAs") to consult with parents in developing their Title I plans. See 20 U.S.C. $\$ 6311$ (a) (1994). However, this provision is neither detailed nor particularly clear. The school-and district-leveI provisions discussed here are found in a separate "parent involvement" section of the Act, 20 U.S.C. $\$ 6319$ (1994), to which this discussion is dedicated.

98. See 20 U.S.C. \$ 6319(a)(2).

99. See id. \$ 6319(a)(2)(A); see also id. \$§6312, 6317.

100. See, e.g., Rogers, supra note 64 , at 4 (expressing the concern that parents are often marginalized in decision making under prior and new law). Perhaps House conferees were attempting to mitigate the risk of parent marginalization when they amended the original bill to state: "If the [district's Title 1] plan ... is not satisfactory to parents of participating children, the local educational agency shall submit any parent comments on the plan when it submits such plan to the state for approval." H.R. CoNF. REP. No. I03-761, at 622 (1994). For some reason this change was not added, as conferees had agreed, to the subsection on districts, but to the subsequent provisions on school-level policies. See 20 U.S.C. § 63I9(b)(4). 
overall goal of allowing state and local officials a measure of flexibility in their program designs. ${ }^{101}$

The district's written parent involvement policy must also explain how the district will support schools in implementing their own parent involvement policies; help build schools' and parents' capacity to work together; integrate parent involvement strategies from a variety of federal and other programs; and annually evaluate, with parents, the written parent involvement policy for effectiveness, altering it if necessary.$^{102}$ Perhaps in an effort to ensure some tangible activity through these provisions, the Act mandates that districts reserve at least one percent of their Title I moneys for parent involvement activities at district and school levels and that they involve parents in budgeting these funds. ${ }^{103}$

In our example, the parent involvement policy of Hesperian School's district, San Lorenzo Unified, does not specifically address the manner in which parents will be involved in policymaking. Instead, it is an aspirational document, setting out principles and general goals. It states that parents should be informed about their children's learning and engaged in helping them learn both at home and at school. ${ }^{104}$ It also says that the schools will make an effort to involve parents in "instructional and support roles at the school" and in "governance, advisory, and advocacy roles." 105 It does not address how the district will do any of the work of supporting parent involvement required by the Act. ${ }^{106}$ Furthermore, Hesperian's principal, Barbara DeBarger, does not think parents were involved in writing this policy. ${ }^{107}$

101. See, e.g., 60 Fed. Reg. 34,819 (1995) (noting that, in response to complaints that the final regulations do not elaborate parent involvement requirements. "the progress of a school is measured on the basis of student achievement, not the process to elicit that achievement").

102. See 20 U.S.C. $\$ 6319(\mathrm{a})(2)(\mathrm{B})-(\mathrm{F})$.

103. See id. at $\$ 6319(\mathrm{a})(3)$.

104. See generally Rules and Regulations, Policy No. 916, San Lorenzo Unified School District, San Lorenzo, Cal. (1993).

105. Id.

106. In its defense, it must be noted that San Lorenzo Unified has not amended its policy on parent involvement since before the IASA was enacted. The former law required districts to develop policies on parent involvement, with parent consultation, but did not specify the topics to be covered in such a policy. See Augustus F. Hawkins-Robert T. Stafford Elementary and Secondary Improvement Amendments of 1988, Pub. L. No. 100-297, § 1016(c), 102 Stat 140, 157. In addition, San Lorenzo does have a rule implementing its policy that states: "Each school will ... [i]nclude in the yearly plan parent involvement as an aspect of the School-Based Coordinated PIan." Rules and Regulations, Policy No. 916, San Lorenzo Unified School District, San Lorenzo, Cal., I (1993).

107. See Interview with Barbara DeBarger, supra note 96. Although the policy was adoptcd in 1993, before the 1ASA was passed, the prior law imposed nearly identical requirements upon districts with respect to involvement required in policy writing. The IASA's principal amendment to the policy-writing requirements extends the parental involvement requirement to individual schools. Conpare Augustus F. Hawkins-Robert T. Stafford Elementary and Secondary Improvement Amendments of $1988 \S 1016$ with 20 U.S.C. $\S 6319$ (a) (1994). 


\section{ii. School-level advisory roles}

Surprisingly, the IASA's predecessors did not always require individual schools to involve parents in any way. ${ }^{108}$ The new law, in contrast, focuses most of its requirements on the school level. Each school receiving Title I funds must "jointly develop with, and distribute to," Title I parents a written parental involvement policy. ${ }^{109}$ The policy must describe how the school will involve parents in policymaking, as well as how the school will promote shared responsibility for high student performance, build capacity for involvement, and ensure accessibility even to parents with disabilities or limited English proficiency. ${ }^{110}$ Each of these four subjects of concern is elaborated in subsequent provisions of the Act. ${ }^{\text {II }}$

As with district-level parent involvement, parents at each school are to join school staff in prescribing how parents will be involved in program planning. The Act sets out several minimum standards for parent involvement. First, schools-not districts, as in the prior version of the ESEA $^{112}$ - must convene an annual meeting for all Title I parents, at which Title I requirements and parents' right to be involved shall be explained." Second, schools are to offer "a flexible number of [additional] meetings," and may use Title I funds to pay for expenses such as child care and transportation for such meetings. ${ }^{114}$ The purpose of these additional meetings is not clearly conveyed. However, the general purpose may be gleaned from the third requirement, that schools involve parents "in an organized, ongoing, and timely way, in the planning, review, and improvement" of the school's Title I programs. ${ }^{115}$

In its effort to meet these requirements, Hesperian adopted its district office's parent involvement policy, mentioned above, almost verbatim. ${ }^{116}$ The Hesperian council only revised the district policy by inserting its name and adding some examples of "effective, ongoing communication between home and school," by way of various newsletters, "conferences, and Family education nights."

108. Prior to the 1994 amendments, the law applied its parent-involvement requirements to districts and not to individual schools. See Augustus F. Hawkins-Robert T. Stafford Elementary and Secondary Improvement Amendments of 1988 \$ 1016; see also supra notes $82-91$ and accompanying text.

109. 20 U.S.C. $\$ 6319(\mathrm{~b})(1)$ (1994).

110. See id. $\$ \$ 6319(\mathrm{~b})(1),(\mathrm{c})-(\mathrm{f})$.

111. These provisions are discussed below in Part 11.B.1.b-c.

112. See supra note 108 .

113. See 20 U.S.C. $\$ 6319$ (c)(1) (1994).

114. Id. $\$ 6319$ (c)(2).

115. Id. $\S 6319$ (c)(3).

116. See supra note 104 and accompanying text.

117. Hesperian School Parent Involvement Policy, 1996-97 (Hesperian School, San Lorenzo, Cal.). 
Hesperian's actions may be permissible under Title I. Title I's subsection on school-level policy involvement provides that "[i]f the local educational agency has a school district-level parental involvement policy that applies to all parents, such agency may amend that policy, if necessary, to meet the requirements of this subsection." this provision's location and use of "this subsection" means that a district policy could be amended to meet the school-level parent involvement policy requirements. However, since school-level policies must be "jointly develop[ed] with" Title I parents, ${ }^{19}$ it is unclear how schools would meet their obligations by amending a district's existing policy that was not developed with parents from a particular school. ${ }^{120}$

Principal DeBarger says that Hesperian's school-site council adopted the district's policy. This council is not a Title I council, but rather was designed pursuant to state law and contains staff and parents in an equal proportion, including only two parents of Title I children. This fairly token participation of target parents may also be permissible under the Act, which provides that if a school already involves parents in designing its programs, that process is acceptable if Title I parents are "adequately" represented. ${ }^{121}$

\section{b. School-parent compacts}

As the title of the IASA's subsection, entitled "Shared responsibilities for high student performance"122 suggests, its drafters wanted to emphasize both parent and school responsibility in achieving Title I's aims of raising standards and performance among its target children. ${ }^{123}$ To this end, each school receiving funds is to develop jointly with parents a compact that sets out "how parents, the entire school staff, and students will share the responsibility for improved student achievement ${ }^{\prime 124}$ and describes how parents and schools will build a partnership in pursuit of their children's progress. ${ }^{125}$ The subsection appears to contemplate a school-wide policy document rather than, for example, an individualized parent-teacher contract. The compact should describe the school's responsibilities in providing a high-quality curriculum and an effective learning environment as well as the parents' responsibilities for supporting their children's learning. Examples of the latter are provided

118. 20 U.S.C. $\$ 6319(b)(3)$.

119. See supra note 109 and accompanying text.

120. See supra text accompanying note 107 .

121. See 20 U.S.C. at $\S 6319$ (c)(3). "Adequate representation" is not defined in the statute.

122. Id. $\$ 6319(\mathrm{~d})$.

123. See, e.g., Hearing on H.R. 3130, supra note 73 at 12 (prepared statement of Richard Riley, Secretary, Dep't. of Educ.) (arguing that schools cannot ensure student achievement without a partnership with parents).

124. 20 U.S.C. $\$ 6319$ (d).

125. See id. 
in the statute: monitoring attendance, homework . and television watching; volunteering in the classroom; and participating in decision making about the school's programs. ${ }^{126}$ The compact shall also address the value of parent-teacher communication. The Act prescribes the minimum bases for such communication: annual parent-teacher conferences, frequent reports to parents on their children's progress, and reasonable access to school staff, including opportunities to observe or participate in their children's classrooms. ${ }^{127}$

Hesperian's school-site council adopted a school-parent compact by selecting from several models provided to the school by the California Department of Education. Hesperian made no substantive changes. ${ }^{128}$ The compact contains pledges to be signed by each student, parent, teacher, and principal. ${ }^{129}$ Principal DeBarger intends to have the compact published in the school's parent handbook that is sent home at the beginning of each school year. She says the compact contains all that the law requires, but she notes that it's "just a piece of paper."130

\section{c. "Building capacity for involvement"131}

The Act's last major subsection on parent involvement reads like a laundry list of ideal practices to support parent-school cooperation and, taken in earnest, would lead to a very extensive partnership program. Titled "building capacity for involvement," the subsection applies broadly to both districts and schools, ${ }^{132}$ perhaps lending it an even more vague and idealistic tone. The first provisions, which are mandatory, require districts and schools to distribute information to parents in order to enable them to understand the relevant laws and standards and to work with their children on their academic progress. ${ }^{133}$ The provisions also require (1) other materials and training to be provided to parents; (2) staff training in the value and methods of involving parents in school; (3) coordination and integration of parent involvement activities with those of other programs; (4) "appropriate roles" for communitybased organizations and businesses in parent involvement activities; (5) other social support for families; and (6) information in parents' first language, if possible. ${ }^{134}$

126. See id. $\S 6319(\mathrm{~d})(1)$.

127. See id. \& 6319(d)(2).

128. Compare Hesperian School Parent Involvement Policy, 1996-97, supra note 117 with Compensatory Educ. Office, Cal. Dep't. Educ., Sample School-Parent Compact for COMPENSATORY Education Programs 3 (1995).

129. See Hesperian School Parent lnvolvement Policy, 1996-97, supra note 117.

130. Interview with Barbara DeBarger, supra note 96.

131. 20 U.S.C. at $\$ 6319(\mathrm{e})$.

132. See id.

133. See id. at $\S 6319(\mathrm{e})(1)$.

134. See id. at $\S \S 6319(\mathrm{e})(2)-(7)$. 
The "building capacity" subsection also contains several permissive uses of Title I funds, including involving parents in staff training; training parents to recruit other parents to get involved in school activities; and arranging home visits by teachers for parents who are unable to come to the school. ${ }^{135}$ The final provision in the subsection requires schools and districts to provide "other reasonable support for parental involvement activities ... as parents may request."136

During the 1995-96 school year, Hesperian held family education nights but never tried to extend their efforts to the home. Principal DeBarger says that the many activities the new law requires are good goals, and that the law "provides a focus" and reminds schools to "take every opportunity to educate parents." 137 She notes, however, that the targeted population is difficult to reach and that her school will have difficulty doing staff and parent training without support and guidance from the district office. She says district officials offer such support at times, but do not make specific commitments. "We have to seek it out if we want it," she says. ${ }^{138}$ She also admits that unless she and other school officials are forced to do this kind of work, "we are so busy, we won't think about it." 139 Thus school administrators likely will overlook the many permissive provisions in the law. Further, even as to the mandates, DeBarger says "the only way schools will be accountable to this is through compliance review," which takes place every four years. ${ }^{140}$

In sum, the IASA imposes a very detailed set of parent involvement mandates on schools and school districts, but the requirements are not very clear and do not seem likely to produce much substantive change in home-school interaction. The Act directs school bureaucracies and local staff to produce paper policies and agreements but does not set out the work that parents and schools will do to improve children's learning. The next section discusses this failure in terms of the school and parent impact models described in Section I.

135. See id. at $\$ \S 6319(\mathrm{e})(8)-(14)$.

136. Id. at $\S 6319(\mathrm{e})(15)$. A final subsection of the IASA's parental involvement section requires schools and districts to provide information about parent resource centers, if such centers exist in that state pursuant to the Goals 2000: Educate America Act, 20 U.S.C. § $580 \mathrm{I}$ et seq. (1994). See id. at § $6319(\mathrm{~g})$. The Goals 2000 Act sets eight national education goals, one of which is increased parent involvement in their children's education. See 20 U.S.C. § 5812(8) (1994).

137. Interview with Barbara DeBarger, supra note 96.

138. Id.

139. Id.

140. Id. 


\section{III}

\section{CRITIQUe OF THE IASA}

Both Congress and the Department of Education sought to use the Title I parent involvement provisions to raise academic achievement among the target student population. However, the IASA neglects parent impact techniques as tools for reaching this goal. The IASA has, perhaps by accident of history, primarily utilized school impact techniques, but without the commitment to structural change required to improve schools through parent empowerment. As this section demonstrates, the cost of this mistake is a failure to encourage schools to implement parent impact techniques that have real potential for improving children's academic success.

\section{A. Advantages of the Parent Impact Approach in Raising Academic Achievement}

\section{Evidence in the Educational Literature}

Parent impact techniques, particularly those that focus on helping parents teach their children at home, can have significant positive effects on student achievement. ${ }^{141}$ Parent roles that focus on children's educational progress are superior to roles that seek to change the school through parent involvement in decision making. Parent impact techniques allow for greater parent participation and more direct influences on academic achievement, and they are more consistent with parental preference.

\section{a. Breadth of Involvement}

Most obviously, parent impact techniques have a greater effect on student achievement because they provide broader scope of opportunity for parent involvement. The parent impact model stresses the role parents naturally play as teachers of their own children. ${ }^{142}$ Parents ordinarily spend time attending to their children, and the parent impact model seeks to direct some of that attention to learning activities that build their children's academic skills. ${ }^{143}$ The effects of parent impact roles contrast sharply with the results of parent involvement on advisory committees. By necessity, only a small sample of a school's parents can be involved in governance activities in the school impact model. ${ }^{144}$ At best, most parents would be involved in decision making only by

141. See Moore, supra note 49 , at 143 .

142. See, e.g., Olmstead, supra note 26 , at 225.

143. See, e.g., Rich, et al., supra note 52 , at 30 .

144. See Comer, supra note 27, at 141 (estimating that in New Haven's School Development Program 1-5\% of parents participated in school governance, $10-25 \%$ in school-day activities, and 50$100 \%$ in "broad-based activities"). 
electing their peers as representatives. This involvement, however, is both unlikely and insubstantial. For example, most shared decision-making projects have had "dismally" low turnout for elections. ${ }^{145}$ A low level of participation is especially common for low-income and minority parents, ${ }^{146}$ who are the least likely to be involved in school programs in the first place, but whom the federal government is most interested in involving. By contrast, parent roles that focus directly on their own children can involve as many parents as are willing to as great a degree as they are able.

\section{b. Influences on academic achievement}

Most significantly, focusing parental participation on their own children's learning improves children's academic success. ${ }^{147}$ In addition to the direct teaching function of parent tutoring, parental attention to their children's learning can improve school success by communicating high academic expectations to children and conveying the importance of homework. ${ }^{148}$ Studies indicate that parent tutoring reduces the disadvantages of poor children's socio-economic status, ${ }^{149}$ which is exactly the objective of Title I parent involvement.

On the other hand, for those few parents who do respond to invitations to help govern a school, their roles are only indirectly related to student achievement. Researchers consistently have failed to find that parent advisory work contributes to higher student achievement, while they have shown that direct involvement of parents with their children at home and at school improves performance. ${ }^{\text {so }}$ Studies of parent involvement in federal compensatory education programs, including Title I, confirm these findings. ${ }^{151}$ Not only are these disparate results due to the limited participation possible in advisory capacities, ${ }^{152}$ but they also reflect the nature of the role. Parent advice at a school must focus on general programmatic and policy questions, whereas parent tutoring roles focus directly on children's learning.

145. See Jane L. David, School-Based Decision Making: Kentucky's Test of Decentralization, 75 Phi Delta Kappan 706, 708 (1994); see also Rich et al., supra note 52, at 29.

146. See David, supra note 145 , at 708.

147. See Rich et al., supra note 52, at 29.

148. See Moore, supra note 49 , at 142.

149. See id. at 143.

150. See Leler, supra note 40 , at 163; Moore, supra note 49, at 143,145-46; Rich et a1., supra note 52 , at 29 .

151. See J. Ward Keesling \& Ralph J. Melaragno, Parent Participation in Federal Educatiun Programs: Findings from the Federal Programs Survey Phase of the Study of Parental Involvement, in Parent Education, supra note 40, at 230, 236, 238.

152. See id. at 237 (reviewing study that found that, in Title 1 programs, few parents were even aware of the existence of Parent Advisory Councils). 
However, parent advisory roles may affect academic achievement indirectly through parents' contributions to their children's school programs. This effect is a key assumption underlying the school impact model. ${ }^{153}$ Parents may have a positive effect on educational programs through roles in program planning ${ }^{154}$ or through their influence on staff selection. However, such effects seem to require meaningful control over these significant areas of school administration ${ }^{155}$-control that the federal government is currently unwilling, and perhaps unable, to mandate at the local level. ${ }^{156}$

School impact techniques also might affect academic achievement through their educative effect on school staff, particularly teachers. Through increased and diversified contacts with parents, teachers can learn to communicate with parents in a positive and productive way, thus contributing to school effectiveness. ${ }^{157}$ These contacts may be particularly beneficial in school settings where parents and teachers mistrust or undervalue one another's willingness to cooperate. ${ }^{158}$ While such an effect on academic achievement may arise indirectly out of shared governance schemes in the schools, ${ }^{159}$ productive communication and cooperation could just as easily result from other forms of schoolparent contact, such as frequent parent-teacher conferences, parents' presence in classrooms or on field trips, and home visits by school staff..$^{160}$

In addition, members of parent advisory councils, insofar as they become knowledgeable about the school's programs and needs and become comfortable with the school staff, may become effective recruiters of other parents for involvement in school activities. ${ }^{161}$ Parent-to-parent communication is an important accomplishment for any parent

153. See Leler, supra note 40 , at 143.

154. See, e.g., Comer, supra note 44 , at 5 .

155. Even conferring real power on parents does not, of course, guarantee an appreciable effect on student achievement. Recent Chicago reforms giving significant power to local school councils have shown that strong councils produce strong reform efforts but not necessarily academic gains. See John Q. Easton \& Sandra L. Storey, The Development of Local School Councils, 26 Educ. AND URB. Soc'y 220, 221 (1994); Herbert J. Walberg \& Richard P. Niemiec, Is Chicago School Reform Working?, 75 PH Delta Kappan 713, 714 (1994) (finding a drop in standardized test scores during the first three years of reform).

156. See infra Part III.B.I.c.

157. See Cochran \& Dean, supra note 46 , at 264.

158. See infra notes 211-221 and accompanying text. Parent involvement programs may include training workshops for teachers to help overcome this problem. See, e.g., Cochran \& Dean, supra note 46 , at 264 .

159. See Michelle Fine, [Ap]parent Involvement: Reflections on Parents, Power, and Urban Public Schools, 94 Teachers College ReC. 682, 694-695 (1993) (quoting parent advisors who say that camaraderie eventually developed between teachers and parents and that without parent involvement in policy-making, decisions wouId be narrow-minded).

160. See, e.g., Epstein, supra note 19, at 1143; Olmstead, supra note 26, at 226.

161. See Comer, supra note 44 , at 5 . 
involvement program and ought always to be strongly encouraged. But again, advisory council members are not more apt to fill this role than parents whom the school reaches through other means. ${ }^{162}$ Indeed, the more significant the work of parent advisors, the less time they have for outreach, a distinctly different project than developing policies and studying curricula. Thus, even indirect effects upon student success do not set the school impact model apart from the more modest parent impact model.

\section{c. Parent preference}

The best reason to emphasize the parent impact model over the school impact model may be parents' preference for direct involvement with their children. Researchers have found that parents' primary motivation for school participation is to help their own children do well academically. ${ }^{163}$ Not surprisingly, experience shows a higher actual rate of involvement in traditional child-centered models than in decisionmaking models. ${ }^{164}$ Some studies note that people tend to prefer active participation to advisory roles, ${ }^{165}$ and that "the parent-as-tutor approach appeals to the most basic parental motivation for involvement in the first place-the desire to help one's child do better in school."166

Clearly, parent involvement can help raise academic achievement through the direct assistance that parents provide to the school when they act as teachers, at home or in the classroom. ${ }^{167}$ Such a result may be especially likely with participants in compensatory education programs. Time spent at home on reading and other activities can replace or enhance remedial school programs aimed at raising children's proficiency levels. ${ }^{168}$ In contrast, parent involvement in decision making has, at best, an indirect effect on student achievement.

162. See Joyce L. Epstein, A Response, 94 Teachers College Rec. 710, 712 (1993) (suggesting that although some parent councils may take steps to involve other parents in other ways, increased participation is more likely to require separate program development initiatives).

163. See Susan L. Dauber \& Joyce L. Epstein, Parents' Attitudes and Practices of lnvolvement itt Inner-City Elementary and Middle Schools, in Families and Schools IN A Pluralistic Society 53, 68 (Nancy Feyl Chavkin ed., 1993); see also Lewis \& NaKaGawA, supra note 54, at 102 (reporting that parents prefer supportive rather than policy activities).

164. See Anne T. Henderson et al., Beyond the Bake Sale: An Educator's Guide to Working with Parents 11 (1986); see also John W. Alden, Needed: A Broader Definition of Citizen Participation, in PARTNERS: PARENTS AND SCHOOLS, supra note 32, at 80, 82-83.

165. See Alden, supra note 164 , at 82 .

166. Rich et al., supra note 52, at 29.

167. See Hobson, supra note 32, at 41.

168. See Epstein, supra note 19, at 1142 . 


\section{Further Evidence: The Administrative and Congressional Records}

Both Congress and the U.S. Department of Education, which wrote the bulk of Title I's parent involvement provisions, made clear their interests in child-centered parent involvement practices. This endorsement further buttresses the wisdom of emphasizing parent impact techniques over school impact.

In his advocacy for IASA parent involvement, Education Secretary Richard Riley often emphasized the importance of focusing parents' attention on their own children's learning: ${ }^{169}$

Thirty years of research ... tells us that the starting point of American education is, number one, parent expectations of their children. Parental involvement with their children's education flows from that. This consistent finding applies to every family, regardless of the parents' station in life, their income, their educational background. A child who grows up reading for fun is a child who generally is on the road to success when it comes to learning. ${ }^{170}$

Indeed, the Department of Education had ample opportunity to frame Title I parent involvement in terms of parents' direct influence on their children. The officials who worked on the legislation were readily familiar with the research on the subject, including most of the literature previously described. ${ }^{171}$ In addition, the Department, in response to its request, received comments from the public on reauthorization of the ESEA which clearly prioritized parent training and home-based learning. ${ }^{172}$ Thus, the Department's studies of Title I parent involvement, including its own research and its review of the literature, consistently reveal a concern with direct parent-child interaction as the fundamental mode of successful parent involvement. ${ }^{173}$

Members of Congress also had occasion to consider the value of direct participatory roles for parents in Title I programs. In the Senate hearing on parent involvement in early childhood education in April,

169. See Hearing on H.R. 3130, supra note 73, at 12.

170. Promising Practices, supra note 76, at 7 (statement of Richard Riley, Secretary, Dep't. of Educ.).

171. See Telephone Interview with Jessica Levin, supra note 91.

172. See Pelavin Associates, Inc., Summary of Public Comments Regarding the Reauthorization of Elementary and Secondary Education Programs: Final Report 9 \& Appendix at I8(1992).

173. See U.S. Dep't. of Educ., Statement of the Independent Review Panel of the National assessment of Chapter 1, $50-51$ (I993); Carrie B. Chimerine et al., Policy Studies Associates, InC., The OTher 91 Percent: Strategies to Improve the Quality of Out-of-School Experiences of Chapter 1 Students: SupPlement to the National AsSESSMENT OF Chapter I, 48 (1993); see also ElEMENTARY AND SECondary Educ. Division, U.S. Dep't of Educ., Mapping Out the National Assessment of Title I: The Interim REPORT 53 (1996) (emphasizing parent involvement in homework activities, especially reading, as part of plan for the new Title I assessment). 
1994, ${ }^{174}$ Mimi Doores, an elementary school principal from Maryland, described her school's success at involving parents through its Head Start transition program. ${ }^{175}$ She described how parents are made to feel welcome at the school through meetings and activities during the children's classes and in the evening, when parents' needs and concerns are discussed. ${ }^{176}$

We send home monthly activity sheets in both English and Spanish, which help parents understand what their children are learning and to empower them to teach their own children. Parents are offered training, and the children take home a [Parent Involvement in Basic Skills] box, filled with .... paper, crayons, pencils, paste, glue, scissors, whatever might be needed to do an activity at home. ${ }^{17}$

Ms. Doores also said that every year the program provides each participating child with five books, which contain tips for parents on how to make reading a family activity. ${ }^{178}$

Similarly, at a subcommittee hearing on the ESEA, House members discussed the importance of getting parents directly involved in their children's learning. When one of the witnesses, Robert Slavin, emphasized the importance of mutual school-family support, ${ }^{179}$ the subcommittee chairman asked how to accomplish this. Mr. Slavin, a researcher on schooling for disadvantaged students, said that one of the most successful activities he had used was called "Books and Breakfast." 180 The school invited parents and their children to a breakfast where teachers demonstrated reading activities they use in the classroom. The parents had a chance to practice these same activities with their children at the breakfast. Afterwards, the families took the books home. Mr. Slavin said parents were much more likely to participate in programs "if they are

174. See ESEA: Framework for Change: Hearings Before the Subcomm. on Education. Arts and the Humanities of the Senate Comm. on Labor and Human Resources, 103d Cong. 499 (1994) [hereinafter Framework for Change].

175. See id. at $\mathbf{5 0 3}$ (statement of Mimi Doores, Principal, Beall Elementary School, Rockville, Md.). The Head Start Act provides grants to public or private agencies to provide early childhood education and family services to low-income families. See 42 U.S.C. $\$ \S 9833,9836$ (1994). Its parent involvement requirements are family-service-oriented, emphasizing a focus on individual family needs, literacy and training for the parents. See id. $\$ 9837(\mathrm{~b})$.

176. See Framework for Change, supra note 174, at 504 (statement of Mimi Doores).

177. Id.

178. See id.

179. See Hearing on Innovative Approaches for Teaching Disadvantaged Students: Hearing Before the Subcomm. on Elementary, Secondary, and Vocational Educ. of the House Comm. on Educ. and Labor, 102d Cong. 5, 57 (1992) (statement of Robert Slavin, Director, Early and Elementary School Program, Center for Research on Effective Schooling for Disadvantaged Students, Johns Hopkins University, Baltimore, Md.).

180. See id. at 57 . 
going to do something with their kid than if you just have them come to back-to-school night and so on." $" 181$

The Act's committee print, which is the compilation of recommendations to Congress from national organizations, also emphasizes direct parent-child interactions. In particular, the Commission on Chapter I, a national oversight group impaneled by Congress under the ESEA, submitted very extensive drafting recommendations that emphasized this type of involvement. ${ }^{182}$ The Commission recommended that schools be required to provide training to parents in "helping their children learn more effectively" and to develop and disseminate home-based learning materials. ${ }^{183}$

Despite strong support in the literature, the keen interest of the Department of Education, and the evidence put before Congress, the Act does little more than mention child-centered forms of parent involvement. For example, the Act says the school-parent compact should suggest ways that parents could support their children's learning, such as "monitoring ... homework completion" and volunteering in the classroom. ${ }^{184}$ Recall that the compact is a piece of paper, likely to have been adapted from a template, that sets out a "generic" arrangement between parents, students, and schools. ${ }^{185}$

In the IASA's "building capacity for involvement" section, districts and schools are to provide materials and training to parents, such as training in working with their children to improve their achievement, including "coordinating necessary literacy training from other sources" for parents who need it. ${ }^{186}$ These are the only parts of Title I that concern parent involvement to influence directly children's academic progress.

Although these provisions indicate that the IASA's drafters had some interest in encouraging parents to participate directly in their children's learning, they clearly represent a low priority within the Act as a whole. As Hesperian School's Principal DeBarger noted, one might expect that, with parents' policymaking roles taking such a dominant place in the requirements schools and districts must address, these straggling provisions would often be ignored, almost by necessity. ${ }^{187}$

181. $I d$.

182. See 1 Subcomm. ON Elementary, SECONDARY, AND Vocational educ., House of REP., 103D CONG., Legislative Recommendations for Reauthorization of the Elementary and Secondary Education act and Related Measures 216-17 (Comm. Print 1993) [hereinafter LEgISLATIVE RECOMMENDATIONS].

183. Id. at 217.

184. 20 U.S.C. $\$ 6319(d)(1)$ (1994).

185. See supra text accompanying notes 122-130.

186. 20 U.S.C. $\$ 6319$ (e)(2).

187. See supra text accompanying notes 137-140. 
B. School Impact: In the Wrong Place at the Wrong Time

While the IASA did not utilize parent impact techniques very prominently, the school impact technique dominates the Act. In light of the poor fit between this technique and improving academic achievement, and given the dearth of legislative history on the Act, what its drafters sought to achieve through this emphasis is unclear. The most plausible answer is that the Act attempts to make schools more responsive to their communities through parent empowerment. If parents had a hand in shaping the policies and programs of their children's schools, those schools would be more accountable to the educational needs of their children and would produce more appropriate and successful programs. This argument fails to support the use of school impact in Title I. First, empowering parents in this way is very difficult, mostly because of predispositions on the part of school professionals and parents. Second, the federal government is the least apt to provide the inspiration for such systemic change because of its distance from the school-site level.

As an initial matter, parent empowerment may have a different meaning today than it did when parent involvement first appeared in Title I. When the ESEA was first enacted, parent empowerment meant an adversarial, political watchdog role for parents. ${ }^{188}$ Parent advisory councils were mandated by law to monitor the federal programs at the school and district level. ${ }^{189}$ Unfortunately, parent advisory councils were easily co-opted by school administrators. ${ }^{190}$ Federal programs encouraged schools to focus on an advisory role for parents, while parents were more interested in supporting the schools and helping their own children than in making policy or interfering in areas traditionally controlled by school professionals. ${ }^{191}$

Advocates of school reform and the federal government have largely abandoned the adversarial model. The majority of educational literature on parent involvement advocates, somewhat uncritically, all forms of participation, including decision making. ${ }^{192}$ However, most recent literature advocates "school-family partnerships" in which parents are participants in decision making, not a power faction with which schools are forced to reckon. ${ }^{193}$ Some have even suggested that an

188. See Harriet T. Bemstein \& Daniel W. Merenda, Categorical Programs: Past and Present, in The Federal Role in Education: New Directions for the Eighties 51, 65 (Robert $A$. Miller ed., 1981).

189. See id.

190. See id. at 65-66; Don Davies, ET. AL., Federal AND State IMPACt on Citizen Participation in the Schools, 14-15 (2d ed., 1979).

191. See, e.g., Alden, supra note 164, at 81-83.

192. See generally New GeNeration, supra note 7 (providing detailed abstracts from 66 studies on family involvement in education).

193. See, e.g., id. at 15-16. 
ineffective school council, characterized by adversarial relations between parents and teachers, serves the central bureaucracy by putting it in a mediator role rather than that of a target. ${ }^{194}$

The use of the term "partnership" by the Secretary of Education in a variety of contexts ${ }^{195}$ indicates that this more harmonious conception of shared decision making has spread. Department of Education officials confirm that the IASA provisions were "predicated on cooperative partnerships rather than hostile relationships."196 Thus, if improving schools through parent empowerment was the goal for the advisory roles in Title I, it is based on a cooperative conception of empowerment, not an adversarial one.

\section{Problems With Changing Schools Through Increased Parent Control}

Even a cooperative arrangement for parent involvement in policymaking requires some parity of authority between parents and school officials. Given the traditional imbalance of authority over educational policy in favor of school professionals, success in this endeavor seems to require the improbable: significant changes of attitude, particularly among school professionals, but also among parents; local leadership that embraces serious institutional change; and institutional conditions that support such internal change. For the reasons that follow, these conditions are unlikely to be present in most schools or to be influenced by Title I.

\section{a. Parents are not drawn to policymaking}

As noted above, parents express less interest in school policymaking than in helping their own children succeed. ${ }^{197}$ Turnout by parents at advisory meetings and elections is commonly very low, ${ }^{198}$ and in the past, Title I parents often did not even know about the required parent advisory councils. ${ }^{199}$ Even advocates of parent and community control of schools admit that parents are not usually very interested in either the drudgery of group planning processes or the notoriety of overt activism. ${ }^{200}$

194. See Fine, supra note 159 , at $684,699-700$.

195. See, e.g., Strong FAmilies, Strong Schools supra note 8, at 4 (describing a partnership as "a research base for family involvement in learning" designed to serve an informal coalition of families, schools, communities, businesses, and governments).

196. Telephone Interview with Jessica Levin, supra note 91.

197. See supra Part III.A.1.c.

198. See supra text accompanying notes 145-146.

199. See Keesling \& Melaragno, supra note 15I, at 237.

200. See Fine, supra note 159, at 692. 
Moreover, emphasizing parent participation in policymaking is a wise approach for Title I to take only if the participation is likely to influence the school program. Evidence suggests that no matter what type of policymaking role parents take, they are unlikely to approach it with a desire to change schools. Parents often express satisfaction with their children's schools and seem to be more interested in supporting or supplementing the school's work than in reforming it. ${ }^{201}$ One of the most prominent scholars writing on parent involvement notes that when parents express how they want to be involved in their children's education, "[t]hey use words like information, communication, and participation" rather than "power, authority, and control."202 When parents take a supportive rather than a reform-oriented approach, ${ }^{203}$ their involvement on advisory boards tends to support the status quo. ${ }^{204}$ In addition, parent involvement in policymaking may take away time and energy that could be spent on their own children. ${ }^{205}$ These results would seem to dilute any impact Title I might have on improving academic achievement.

\section{b. The power of inertia: parents, teachers, and authority}

Even if parental policymaking roles were popular, their main pitfall lies in the institutional and personal transformations they require. Many observers have written that empowering parents in this way cannot be effective without a significant shift in the balance of power in schools, ${ }^{206}$ so that parents and teachers see that they truly have a stake in cooperating. ${ }^{207}$ This signals a serious design problem in Title I. By requiring schools and districts to initiate policy consultations with Title I parents, the Act relies on the very groups that research has proven to be unwilling or unable to begin the parent involvement process. ${ }^{208}$

Parent empowerment seeks to modify the traditional boundaries between parents and schools by giving parents influence over areas

\footnotetext{
201. See Lewis \& NAKAGAWA, supra note 54, at 101-02.

202. Epstein, supra note 162, at 715 (emphasis omitted).

203. See Lewis \& Nakagawa, supra note 54, at 165.

204. See id. at 126.

205. See id. at 146 (quoting one council member: "'I was pissing away time there, I could have been at home with my son, helping him with his homework."').

206. See, e.g., Cochran \& Dean, supra note 46, at 266.

207. See Comer, supra note 28 , at 117.

208. See McLaughlin \& Shields, supra note 17 , at 157 ; see also Steinberg, supra note 45 , at 54 55 (criticizing federal programs for turning over implementation of parent advisory programs to local school boards and administrators). This paradox is all the more striking if one assumes, as the Act suggests, that the few prescriptive features in Title I are intended for schools and districts that currently are not involving parents. Notably, the IASA allows districts and schools that already have parent involvement policies to amend them to meet the Act's requirements. See 20 U.S.C. §§ 6319(b)(2)-(3) (1994). The IASA permits schools to amend the "process for involving parents in the joint planning and design of its programs." $I d$. $\$ 6319$ (c)(3). Probably, the IASA was intended, in part, to allow schools to continue utilizing their parent councils if those existed.
} 
typically controlled by professionals. ${ }^{209}$ However, parents rarely possess the resources necessary to operate independently in these areas. Parents rely on school professionals, whom they were supposedly invited to change, to learn about participating in policymaking. ${ }^{210}$ This structural imbalance likely undermines parent empowerment.

The imbalance between parents and professionals exists even in the cooperative model of parent empowerment discussed above. The imbalance results not only from overt resistance to cooperate on the part of professionals, but also from the less conscious habits and assumptions of both parents and school professionals about the proper roles of parents and teachers in schools. Sara Lawrence Lightfoot has written extensively on the territoriality both parents and teachers feel toward their spheres of influence on a child." She suggests that "ritualistic" occasions of interface serve to establish boundaries and "rarely allow for real contact, negotiation, or criticism between parents and teachers." ${ }^{212}$ Others have noted the rigidity of roles assigned to school staff and parents in their communications, with staff giving information and parents passively receiving it. ${ }^{213}$

Studies find that teachers are often suspicious or resentful of parents who want to be involved, ${ }^{214}$ they may harbor stereotypes about parents' capabilities, ${ }^{215}$ and they may fear parents who seem to question their professional competence. ${ }^{216}$ Similarly, principals, said to be the most important players in initiating a successful policy collaboration project, ${ }^{217}$ also tend to be unwilling or even incapable of ceding significant authority to parents. ${ }^{218}$ To the extent that school professionals are reluctant to collaborate with Title I parents, their positional advantages make the project unlikely to succeed. ${ }^{219}$

By the same token, parents themselves often seem uncomfortable stepping out of traditional supportive roles and into educational program planning. As Lewis and Nakagawa found, Chicago parents elected to councils expected the school authorities to provide them with clear guidelines on what their responsibilities were and the information

209. See Lewis \& NAKaGAWA, supra note 54, at 128.

210. See id. at $129,132$.

211. See, e.g. Sara Lawrence Lightfoot, Worlds Apart: Relationships Between FAMILIES AND SCHOOLS, 25-30 (1978); Lightfoot, supra note 47, at 98-99.

212. Lightfoot, supra note 47 , at 99.

213. See Betty Malen \& Rodney T. Ogawa, Decentralizing and Democratizing the Public Schools-A Viable Approach to Reform?, in EDUCATION REFORM, supra note 42, at 103, 111-12.

214. See Leitch \& Tangri, supra note 38 , at 73 .

215. See id. at 70,73 .

216. See Hoover-Dempsey et al., supra note 20 , at 419.

217. See Leler, supra note 40 , at 172.

218. See Karen Foster, Parent Advisory Councils: School Partners or Handy Puppets?. Principal, March 1984, at 27, 31.

219. See Malen \& Ogawa, supra note 213, at 110-11. 
necessary to carry them out. ${ }^{220}$ Even where a working policy group is in place, parents are likely to feel reluctant to "meddle" in areas traditionally controlled by school staff. ${ }^{221}$

The persistent distinction between parent and professional roles has resulted in parent councils that frustrate, rather than empower, their participants. ${ }^{222}$ In their analysis of Chicago's councils, Lewis and Nakagawa found that because of personal and systemic limitations on parent authority and the struggles over defining their roles, the councils directed their energies toward the process of cooperating rather than the substance of educational reform: "Success meant consensus, getting along." 223 As a result, most parents were hard-pressed to name a single policy they had helped make that would change the schools in any way. ${ }^{224}$ The authors conclude that this empowerment strategy "merely institutionalize[d] these outside voices.... The expression of parent interests-rather than their realization-is a goal in and of itself."22s

This type of parent involvement may actually serve to reinforce the allocation of authority within school systems. Some observers have referred to mandated parent advisory councils as "window dressing, merely rubber-stamping the decisions of school administrators."226 Lewis and Nakagawa report that, whereas decentralization of school decision making works well in middle-class districts, low-income schools do not have the infrastructure or skills to take advantage of these new allocations of authority. ${ }^{227}$ They point out that limiting reform to changes in school governance makes it palatable to white suburban and rural interests because it maintains the status quo in terms of resource allocation. ${ }^{228}$ When issues of educational inequity are devolved to the school level, the schools with the fewest resources are least likely to benefit. ${ }^{229}$ Empowerment strategies, they conclude, tend to filter parent voices "through the prism of middle-class democratic proceduralism." 230

In general, the implementation of parent involvement in educational governance presents a number of problems. Parents are not drawn to policymaking, and they tend to take supportive rather than reform approaches to such work. Traditional roles between educational

220. See Lewis \& Nakagawa, supra note 54, at 132.

221. See Malen \& Ogawa, supra note 213 , at 112.

222. See id. at 107-08; Steinberg, supra note 45 , at 50, 56 .

223. LEWIS \& NAKAGAWA, supra note 54, at 131.

224. See id. at 145.

225. Id. at 170.

226. McLaughlin \& Shields, supra note 17, at 158.

227. See LEWIS \& NAKAGAWA, supra note 54, at 47.

228. See id. at 96 .

229. See id. at 98 .

230. Jd. at 170 . 
professionals and parents are rigid and often seem to turn cooperative decision making into a procedural exercise rather than a transformative one. Although these barriers are not insurmountable, they seem to be especially likely to impede initiatives by the federal government.

\section{c. The federal government and school impact}

Clearly, the attitudes and personalities of school staff, as well as the interests and resources of the parents, have a significant impact on the success of parent involvement programs. Local differences in schoolcommunity relations may be especially important in implementing shared decision-making, where traditional roles are intentionally altered. Indeed, successful shared decision-making programs seem consistently to have arisen out of strong independent local initiatives. ${ }^{231}$ The empirical evidence of such programs often comes from school improvement programs that were initiated and implemented with the assistance of outside organizations. ${ }^{232}$ This kind of intervention in school programs can help focus the school staff and parents on genuine cooperation and "counter[] systemic tendencies to marginalize parents."233

Local variety leads some to suggest that government cannot mandate the exact form parent involvement should take. ${ }^{234}$ And yet many studies suggest that without a specific mandate most schools will not include parents. ${ }^{235}$ The need for specificity seems to arise out of the significant complexity and organizational challenges posed by shared decision-making. These include the need to have adequate and real representation of parents, clear roles for the participants, defined goals and a defined scope of authority within the overall school system, and training for parents and staff in how to work fairly and effectively together. ${ }^{236}$

These needs do not seem particularly amenable to government mandate, least of all federal mandate. In fact, the Department of Education and Congress expressly avoided writing specific guidelines into the policy involvement provisions. This omission occurred despite numerous requests for specific guidance by advocacy groups and the

231. See, e.g., Fine, supra note 159, at 683.

232. FRUChTER ET AL., supra note 19, at 54.

233. Id.

234. See Milbrey Wallin McLaughlin \& Patrick M. Shields, Involving Low-Income Parents in the Schools: A Role for Policy?, 69 Phi Delta KaPpan 156, 157 (Oct. 1987); Robert E. Slavin, Making Chapter I Make a Difference, 69 Phi Delta KaPPaN 110, 114 (Oct. 1987).

235. See, e.g., Steinberg, supra note 45 , at 48,55 (criticizing the parent advisory councils for having ambiguous goals and guidelines); Fine, supra note 159, at 689 (saying that without clear strategy, the project slipped from parent empowerment to crisis intervention on behalf of individual parents).

236. See David, supra note 145, at 702 (discussing the needs of council members in Kentucky under decentralization). 
public. ${ }^{237}$ The conflict between the need for flexibility and demands for specificity has led to Title I's non-committal use of consultive roles in the policy involvement subsection. Instead, policy makers should have recognized the futility of forcing local institutional change and chosen the more modest and feasible parent impact technique.

\section{Why School Impact in the IASA?}

Given the perils of school impact approaches to parent involvement and the clear advantages of parent impact techniques, the persistence of Congress and the Department of Education in stressing advisory roles for parents in Title $I$ is surprising. Three reasons likely explain the inclusion of the policy involvement requirements in the IASA: (1) a lack of clarity in much of the literature; (2) uncritical endorsement by some interest groups; and (3) force of habit. ${ }^{238}$

First, as noted elsewhere, the educational literature tends to advocate all forms of parent involvement in schools. However, even after thirty years of research and experiments, scholars and activists have yet to pinpoint specific practices that a wide variety of schools can replicate successfully. Moreover, most of the literature focuses on local initiatives, where schools have the freedom to tailor their programs to their unique situations. Many are implemented with the help of scholars or activists who can bring extra resources and focus to the programs. ${ }^{230}$

In contrast, Title I parent involvement must be fashioned within the limitations of distant, top-down mandates. Federal policymakers ought to understand this as a significant handicap in their freedom to prescribe the "good practices" that the literature recommends. Unfortunately, the complex and layered IASA parent involvement provisions do not reflect such modesty. Parent impact techniques are more appropriate within these constraints because they call on schools to invite parents to support what schools are doing rather than to change them. While change may be desirable and in many cases critical to the educational success of disadvantaged children, such change should be responsive to student and family needs. Parent impact techniques can bring parents into closer proximity with schools and thereby lay the seeds for empowerment.

237. See Framework for Change, supra note 174, at 221 (statement of Richard L. Nero, Sr., Chairman, National Coalition of Title I/Chapter I Parents); 60 Fed. Reg. 34,800, 34,830 (July 3, 1995); Telephone Interview with Jessica Levin, supra note 91 (stating that some groups, including the Center for Law and Education, "lobbied hard for the PACs").

-238. While these reasons may each or all explain the IASA's preoccupation with parent advisory roles, they are only speculation. As indicated in Part I above, the legislative history is too thin to yield any specific intentions on the part of the Act's drafters.

239. See FruChter et Al., supra note 19, at 54. 
Second, parent advocates have continued to seek strong parent control requirements in Title I. This is understandable. Most scholars and advocates interested in parent involvement are interested in reforming schools. Parent participation in running schools as responsive community institutions is an attractive ideal. But the question Title I parent involvement raises is whether such an ideal can ever be realized through federal initiative. Experience seems to indicate that it cannot. Moreover, attempts like those in the IASA are likely to obscure any less ambitious results that the federal government could accomplish on the path toward that ideal.

Finally, the IASA's emphasis on parent advisory roles may be a result of habit as much as anything else. As noted in Part I, this concept has been with the ESEA since shortly after its enactment in 1965, and its persistence may be a matter of inertia. The problem is that early Title I parent involvement sprang from a different set of policy goals. Commentators have noted that parent involvement in Title 1 originally was "primarily a political rather than an educational move."240 Its principal focus was on parent and community empowerment, not student achievement. While parent empowerment is still a laudable goal, federal policymakers expressed a different one for the IASA: improved student achievement. ${ }^{241}$

\section{IV}

\section{Proposals: Title I Parent InVolvement Should Emphasize PARENT IMPACT OVER SCHOOL IMPACT}

The IASA's emphasis on parents as partners in school policymaking seems to put the cart before the horse. Only after parents become familiar and comfortable with their schools can they begin to take on meaningful policymaking roles. Some of the literature and practice supports this assertion, ${ }^{242}$ and very little contradicts it. ${ }^{243}$ If the leading scholars on the subject are correct that parent involvement "is a stepby-step process of program development, ${ }^{, 24}$ and if the status quo finds

\section{Bernstein \& Merenda, supra note 188 , at 66 .}

241. See supra text accompanying note 18; Executive Summary, supra note 13, at 1.

242. See, e.g., Promising Practices, supra note 76, at 19 (statement of Carolyn Jackson, parent, New Haven, Ct.) (explaining that her process of becoming involved in her daughter's school began with volunteering and that after the principal got to know her and her skills, she was hired at the school and later promoted to a district parent liaison post); Alden, supra note 164, at 83 ("In the process [of volunteering, parents] learn about the needs of our institutions, and they become caring, sensitive advocates for better schools,").

243. See generally NEW GENERATION, supra note 7 (providing an extensive review of parent involvement research and practice, of which very little mentions advisory roles for parents).

244. Epstein, supra note 162 , at 713 . 
neither schools nor parents interested in and capable of policy collaboration, then Title I should focus on the first step, not the last. ${ }^{245}$

The drafters of the IASA parent involvement provisions sought to clarify prior law by reorganizing its components. ${ }^{246}$ They wanted to "recognize the full range"247 of parent roles and identified three key components, which can roughly be called consultation on policies, academic support for children, and institutional support for parents. Measured against the literature, these were good general choices, but the specific provisions are amenable to improvement. The problems with consultative roles were discussed above, and these provisions should be de-emphasized or dropped altogether. The academic support section is terribly weak because when all the verbiage is stripped away, it only requires a piece of paper, a "compact" between parents, teachers, and students that lists a lot of good ideas. And the parent support section, titled "building capacity for involvement," is a cluttered list of good practices, all of which indeed seem desirable, but many of which are permissive only. ${ }^{248}$

Consequently, Congress should amend the Act to change its priorities and significantly alter its details. ${ }^{249}$ The following principles should gnide the amendment of the Act's parent involvement proposals. They should be modest, because they apply to so many widely differing schools, yet firm, so that school administrators will take the requirements seriously. They should also be flexible, so that local needs and initiatives are not stymied, yet clear, so that those responsible may know what is expected of them.

\section{A. Parents Working With Children}

\section{Home-Based Involvement}

School efforts to help parents work with their children at home should be the first priority of Title I parent involvement. This extension of federal influence may seem unwarranted and potentially difficult to achieve. Nonetheless, to boost student success through parent

245. See Framework for Change, supra note 174, at 525-26 (statement of Stuart A. Taylor, II, Bd. of Directors, Youth Guidance, Chicago, III.) (describing the successful Comer model of parent involvement as having three phases: parents familiarizing themselves with the school, becoming active on a daily basis at the school, and joining the management team).

246. See Office of General, Counsel, U.S. Dep't of Educ., The Improving America's Schools Act of 1993, Section-By-Section ANALysis 14 (1993).

247. Id.

248. See 20 U.S.C. $\$ 6319$ (e) (1994).

249. The proposals in this section may require more federal funds than are currently appropriated for Title I. A major premise of this article is that the federal government has properly chosen to make parent involvement an important part of Title I. These proposals are intended to make that federal initiative effective and, considering the bipartisan consensus on the national importance of educational improvement, I proceed despite their potential expense. 
involvement, the federal government must start here. "Home-based parent partnership programs, [in contrast to school-based programs], yield clear academic gains for students, as well as increased levels of parental interest in and support for the schools."250 The IASA's drafters envisioned these very objectives for parent involvement.

Several established local and even nationwide programs already focus on developing and enabling homework projects for families. ${ }^{251}$ According to a recent Department of Education evaluation and review of Title I programs, many have take-home reading programs, lending libraries, and home learning packets. ${ }^{252}$ The Act should first direct the Department of Education to contract with some of the organizations producing successful family homework materials to provide them to schools and districts. Next, it should require Title I schools ${ }^{253}$ to select and utilize these materials. Further technical and human support for parents-as-tutors is discussed below. ${ }^{254}$

\section{School-Based Involvement}

As a complement to the home-based parent-child strategy, Title I should require schools to make an active effort to involve parents as volunteers during school activities. Inclusion of parents in school activities may entail some of the drawbacks of parental advisory roles because many parents cannot provide the time and energy the activities require. ${ }^{255}$ However, requiring schools to invite parent participation is not much to ask. Further, the participation of even a few parents in school activities is better than none. The IASA buries school-site voluntarism in the parent-school compact, where it appears as the last of many items the compact "shall address." 256 Instead, voluntarism should take a front seat because it is the second logical step in parent involvement, serving to familiarize parents with the school as a place and an institution in which they are welcome and useful. While Title I should focus on parents, the basic building blocks of parent involvement, its requirements

250. McLaughlin \& Shields, supra note 17 , at 157 (citation omitted).

251. See, e.g., Fruchter ET AL., supra note 19, at 36-41 (describing two such programsFamily Math and Science, and Megaskills-that have been replicated widely).

252. See ChIMERINe ET AL., supra note 173 , at 38 .

253. As noted in Part 11.A., the law distinguishes between two types of Title 1 schools: those with high numbers of low-income children (permitted to develop "school-wide programs"), and those with lower numbers (limited to "targeted assistance" expenditures). I will retain the distinction in this discussion. However, because Title 1 provides funds so widely, I would excuse schools from these requirements if their Title I grants were below a certain amount, perhaps $\$ 5,000$ annually. See 20 U.S.C. $\$ 6319(a)(3)(A)$ (1994) (excusing districts from requirement of allocating one percent of grant to parent involvement if its grant is $\$ 5,000$ or less). Thus, in this discussion, "Title I schools" refers to schools receiving significant Title I grants.

254. See infra Part 1V.B.

255. See Epstein, supra note 19, at 1143.

256. See 20 U.S.C. $\$ 6319$ (d)(2)(C) (1994). 
should lead to changes in the school. ${ }^{257}$ Even if government cannot mandate change in school professionals' beliefs and practices, it can change behavior in such a way as to lead to changes in beliefs. In some instances, "doing is believing." 258

The law could require that schools make a formal invitation, at the beginning of each term and at each school-wide meeting, ${ }^{259}$ to every Title I parent to volunteer at school. Schools should be required to offer a wide variety of opportunities so that parents with differing skills and interests may realistically consider and take on such roles. The Act could list examples: volunteering in classrooms, on the playground, in the library, in the gym, during after-school activities, and, perhaps most importantly for program development, in recruiting, training, and coordinating other parents.

\section{Biannual School-Wide Meetings}

School-wide meetings are critical because they can serve as the initiating mechanisms for all of the other parent involvement projects. They are also important as a way for parents and staff to socialize in an informal setting. And since the other provisions proposed here are individualized, meetings can have the important effect of demonstrating that a child's parents are not alone in their relationship with the school.

The IASA requires schools to hold an annual meeting. ${ }^{260}$ It should require at least two, one at the beginning of the school year and one at the beginning of the calendar year, so that this recruiting mechanism can be utilized throughout the school year. All school staff should be required to come, and all parents should be invited well in advance. The law could specify that districts or schools should conduct a survey each summer to determine the optimum time, and perhaps place, for such meetings. It also might be appropriate to set attendance goals in the statute, such as $50 \%$ by the second year. District offices should be required to provide translators for any language minorities that exist in significant numbers, as well as child care staff.

257. The importance of parents' regular presence at the school cannot be overstated. Because I recommend de-emphasizing the policy involvement component of the Act, it is especially important to include other mechanisms for exposing the school to its parents, so that it becomes feasible for partnerships to develop in which parents do have an influence on the school's programs. See Framework for Change, supra note 174, at 462 (statement of Patricia Harvey, Former Principal, Hefferan School, Chicago, 1ll.) (saying that her staff found that they needed parents in the building so that staff could listen to their ideas "and then build a program around that").

258. McLaughlin \& Shields, supra note 17 , at 159.

259. See infra Part IV.A.3.

260. See 20 U.S.C. $\S 6319$ (c)(1) (1994). 


\section{B. Support for Parents Working With Children}

The foregoing recommendations-that the Act require schools to use home-learning materials and invite parents to volunteer at schooldo not, by themselves, overcome many of the weaknesses of the IASA identified in this Comment, particularly the institutional obstacles to changing school-parent relations. They remain fairly paper-bound and susceptible to neglect or de minimis compliance. To overcome this problem, the Act must set out practical mechanisms for schools to commit human resources to parent involvement. The Act should do this by requiring schools to hire special staff and offer parent and staff training, and by directing the Department of Education to produce guidance materials.

\section{Parent Liaison Staff}

No single investment seems more apt to facilitate parent involvement than having schools hire a staff person specifically dedicated to the task. ${ }^{261}$ Such paraprofessionals could mitigate parents' limitations by giving them person-to-person contact and making home-visits to families that need them. Liaisons could assist teachers by working with them to develop successful relationships with parents. They also could serve schools by organizing events and coordinating resources from the district, state, and federal authorities.

Parent liaisons are an especially critical commitment to parent involvement because of the psychological and time limits of the regular school staff. If the structure of authority in a school is to change eventually to allow low-income parents to contribute to reform, and if individualized involvement techniques are to enable parents to seek such influence, parents need an avenue through which to do so. ${ }^{262}$ As noted above, preparing parents to serve as partners in school policymaking may be facilitated when schools collaborate with non-school organizations. ${ }^{263}$ In the absence of outside assistance, a school-parent liaison can be a critical asset for both parents and schools.

The law should require each school-wide Title I program to hire at least one such liaison and each district to hire enough staff to serve all

261. See ChImerine ET AL., supra note 173, at $43-44$ (listing the important roles parent liaisons serve in some Chapter 1 programs); Keesling \& Melaragno, supra note 151, at 236 (finding that a key element in the successful federal Follow Through program was the employment of parent coordinators).

262. Congress was advised of this need prior to enacting the IASA. See Legislative RECOMMENDATIONS, supra note 182, at 218-I9 (amendment suggested by the Commission on Chapter 1).

263. See supra notes 231-233 and accompanying text. 
its targeted assistance schools ${ }^{264}$ and to work with the school-based parent liaison staff. Beyond that, the Act should give schools and districts wide discretion in how they use liaisons. It should set out only a very basic job description. It should require that these positions be filled by people able to communicate with at least one of the major language minorities served by the school. Further, the districts should be held responsible for covering unmet needs in this regard. ${ }^{265}$ The Act should require parent liaisons to assist schools in planning and implementing the regular school-wide meetings and the staff and parent training activities, ${ }^{266}$ to organize and manage federal and other materials, ${ }^{267}$ to have a separate telephone line for parents' questions, and to visit children's families as appropriate.

\section{Provision of Resources}

The federal government's most obvious role in public school innovation is to collect and disseminate useful information. ${ }^{268}$ Neither local school staff nor their federal supporters want schools, or even district or state education authorities, operating in isolation from one another. ${ }^{269}$ However, guidance on parent involvement must be useful to many different groups of people, including parents, teachers, and administrators. Instead of promulgating regulations or weighing down the statute with permissive practices, the Department of Education should provide meaningful, easily accessible guidance to these parties.

The Act should direct the Department of Education to publish or commission the publication of handbooks that focus on each parent involvement requirement it enacts. Where appropriate, these handbooks should be produced in versions designed for parents as well as staff. The law could require schools to establish an accessible place-a separate room or a part of the school library, for example-for this and other information on parents and schools which would be available to parents and staff. The parent liaison would be responsible for organizing this "parent library." The law should also require schools and districts to make information on Title I and their own planning, policy, and evaluation materials available to parents through this library. All parents at

264. Targeted assistance schools are those that do not have enough children to qualify for school-wide program status. See supra text accompanying notes 65-66.

265. Regulations accompanying the IASA currently allow schools and districts to counbine Title 1 funds with Title VII Bilingual Education funds for common purposes. See 60 Fed. Reg. 49,174-75 (1995). The law should make this opportunity clear in the area of parent liaison staff.

266. See infra Part IV.B.3.

267. Federal support materials are discussed below in Part IV.B.2.

268. See McLaughlin \& Shields, supra note 17, at I60; Robert E. Slavin, Making Chapter I Make A Difference, 69 Phi Detta Kappan II0, II4-I5 (1987).

269. Telephone Interview with Menachem Herman, U.S. Dep't of Educ. (Mar. 29, 1996) ("We don't want people reinventing the wheel."). 
every Title I school should be formally welcomed to this library and advised of its hours.

\section{Training for Parents}

Parent training is a difficult issue because parent availability, interest, and abilities vary so widely. Some parents will need literacy training before they can work effectively with their children. Others may have substance abuse or other disabling problems. These are problems that the federal government could try to address through public schools. But the funding for these services should be guaranteed separately, before schools are required to administer them. The IASA's approach to literacy training seems appropriate: require schools to inform parents of services available elsewhere in their communities. The Act could improve compliance by requiring district parent liaisons to compile and keep an updated list of local service providers, particularly those of adult education. It should require that these lists be posted near each school's parent resource collection.

In addition, the law should require each school, with the help of parent liaisons, to provide orientation and training to parents on homebased learning materials and on volunteer work at the school. School staff and interested parents must determine the form of these programs. The Act should require districts to produce model materials and training guidance. As with the school-wide meetings, the Act might set goals for attendance levels.

\section{Staff Development}

Successful parent involvement, it has been noted, requires school professionals to alter the way they think and work. It is generally agreed that specialized training for this purpose is critical. "When people are asked to work in a way they are not trained to work or address problems they are not trained to address, one can expect resistance at best, and at worst, floundering, inappropriate, ineffective programs."270 Also, meaningful parent involvement requires strong leadership in each school. ${ }^{271}$ Without it, individual staff members have little incentive to take the time required to involve parents, ${ }^{272}$ and in fact may fear suggesting or implementing significant changes. ${ }^{273}$ While Title I alone cannot create such leadership, the new parent liaisons can provide the structural opportunity for changes in professional practices. Linking the

270. Comer, supra note 27 , at 22.

271. See McLaughlin \& Shields, supra note 17, at 159 (arguing that norm-based pressures may be the most effective tools in facilitating parent involvement).

272. See Hoover-Dempsey et al., supra note 20, at 419.

273. See Malen \& Ogawa, supra note 213 , at 111 . 
parent liaison with some basic staff development activities can elaborate this structural incentive.

Such staff development should focus on the two building blocks: developing and using home-learning materials, and working with volunteer parents. The law should require schools to release teachers from classes on a regular basis, through hiring substitutes if necessary, to attend these training sessions. It should require teachers of the same subject or grade level to meet with each other and the parent liaison to develop home-learning projects, and all school staff to meet at least twice annually to discuss volunteer activities and parent involvement in general. The Act should direct the Department of Education to commission video presentations to aid schools in these conferences.

\section{Potential Mechanisms for Initiating School Impact}

Although parents and communities, rather than the federal government, must initiate parent and community influence on schools ("school impact"), the government could apply some effective spurs. As the literature notes, many of the successful parent involvement programs operate with the assistance of outside groups, often from a university or a non-profit organization. ${ }^{274}$ While this sort of local collaboration does not seem particularly amenable to federal mandate, Title I could encourage such partnerships by allowing schools to develop these partnerships as a substitute for following the Act's parent involvement requirements. In other words, the parent involvement practices required in Title I could serve as a default program, applicable where no locally designed and externally supported program was in place.

This "exemption" provision would create an additional need to determine whether various local partnerships should qualify. At least some of the energy required to evaluate such proposals is currently being expended anyway. The Department of Education offers competitive grants to districts and non-profit organizations to develop parent involvement programs, apart from Title $I^{275}$ The staff energy to collect, evaluate, and select such grant applications could be focused on Title I. ${ }^{276}$ Allowing Title I parent involvement money to be used to develop school partnerships might enable the Department to consolidate its

274. See generally New GeNeration, supra note 7; J. William RIOUX \& NANCY BERLA, INNovations in PARENT aND Family INVOLVEMENT (I993).

275. See, e.g., 60 Fed. Reg. 27,836 (1995); 55 Fed. Reg. 3248 (1990).

276. Assuming this process could, nonetheless, require significant extra work for the department, I urge that a sacrifice of oversight is acceptable in the service of encouraging local initiative. Where schools and local organizations or university groups are able to make the appearance of collaborating on parent involvement, I would give them the benefit of the doubt regarding the substance of that collaboration, absent evidence to the contrary. 
efforts, as well as its funds. Consolidation should also provide interested schools and outside organizations a clearer invitation to collaborate.

In addition to this exemption provision for educational partnerships, Title I could at least allow parent involvement in decision making. The law could direct the Department of Education to provide every Title I parent with a statement that translates the Act's provisions into layperson's terms. The law could also require districts and schools to provide Title I parents the opportunity to work with staff to design the Title I programs. And, as the IASA provides, schools, districts, and states would be required to include comments of dissatisfied parents in the plans they submit to their respective Departments of Education. ${ }^{277}$ The law should also provide that absent good cause, schools and districts that refused to give interested parents a satisfactory role in Title I decisions would be subject to funding cuts or, perhaps less harmful to the school program, increased federal audits and oversight.

\section{An Unresolved Problem: Children Whose Parents Do Not Respond}

The above proposals make a clear break from practices advocated in some of the literature and encouraged throughout most of Title I's history. In theoretical terms, they prioritize the parent impact model and greatly cut back on the school impact provisions. This choice is based on evidence that government cannot require schools to restructure authority appropriately. Such restructuring is likely to occur only upon local initiative. "Parents have generally turned to political activism and demands for shared control only when frustrated by what they perceive as a lack of responsiveness to their needs and concerns."278 Requiring schools to show parents how to become involved in their children's learning seems plausible. These educational partnerships may inspire parents to participate in school policymaking and, in the meantime, they are likely to have a positive effect on student success.

Nevertheless, this approach leaves some problems unaddressed. Most critically, not all children have "parents" through whom they can benefit from parent impact programs. A child's caretaker might not respond to the parent focus suggested here for a variety of reasons. Homeless parents, parents with drug addictions or mental impairments, and otherwise unresponsive guardians may be highly unlikely to respond to school invitations to participate. The lack of responsive parents presents a greater problem in a parent impact model than in a school impact model because the latter could be expected to benefit all children, even if only indirectly.

277. See 20 U.S.C. \$§ 6319(b)(4), (c)(3) (1994).

278. Rich et al., supra note 52, at 29. 
On the other hand, the literature does not clearly demonstrate that even successful school impact models have the effect of changing the school program so much that children with uninvolved parents would appreciably benefit. The benefits of constituent empowerment ideals still flow through the participants, and the unresponsive parents would be equally unresponsive to parent council elections as to invitations to work with their children.

Ultimately, of course, the role schools can play in remedying the deep social and economic inequities that contribute to inequities in school success is limited. Indeed, any intervention into families by educational institutions may be likely to succeed only where it is needed least, leaving the schools and families most at risk of failure in no better position. But the parent impact model may present opportunities to reach the more isolated families that the school impact model does not. One of the critical justifications for having schools hire special liaison staff, and for encouraging school partnerships with outside organizations, is that schools need to pay special attention to children's families. While not a traditional function of schools, this seems an important prerequisite to involving apathetic parents. Thus, while no broadly applicable strategy for parent involvement can guarantee improved learning opportunities for all children, the parent impact model's focus on families is aimed in the right direction.

\section{CONCLUSION}

Parent involvement has won unanimous approval from researchers in the field of education reform, particularly those focusing on remedying educational disadvantage among low-income children. Since Title I is a major educational resource that is focused precisely on this group of students, federal policymakers reasonably may attempt to include parent involvement as one of the Act's goals. Unfortunately, an illadvised emphasis on parent involvement through advisory roles has survived in the IASA, which is intended to take Title I through fiscal year 1999. ${ }^{279}$ This is unwise because parents' impulses to participate in their children's education arise from their desire to help their own children succeed, not to advise schools on programs, policies, and budgets. Although meaningful parent influence on the way schools teach disadvantaged children may ultimately be necessary to achieve true education reform, government, and particularly the federal government, is not in a position to instigate such a transfer of authority at the school level.

Parents want to help their children succeed academically, and they can contribute to that success with some help from schools. Parents of

279. See 20 U.S.C. $\S 6301(a)(2)(1994)$. 
Title I children need this help, and Title I parent involvement ought to require schools to provide it by giving parents materials and staff resources to support parent tutoring. In contrast, requiring schools to build weak councils and paper compacts is not likely to change parents, schools, or children's success. In the meantime, these children pass through our schools year after year with little or no cooperation between their teachers and their parents in helping them learn. 
CALIFORNIA LAW REVIEW 